\title{
Runoff nutrient losses from tall fescue pastures varying in endophyte association, fertilization, and harvest management
}

\author{
D.M. Endale, H.H. Schomberg, A.J. Franzluebbers, D.S. Seman, D.H. Franklin, and J.A. Stuedemann
}

\begin{abstract}
Tall fescue (Lolium arundinaceum [Schreb.] S.J.Darbysh.) is a widely adopted cool-season perennial forage in the southeastern United States. Historically, tall fescue contained a symbiotic fungal endophyte, Epichloë coenophiala, that produced an ergot alkaloid toxic to livestock. New fescue biotypes have been developed that are endophyte free or include endophytes that produce low-toxicity alkaloids. Ecological implications of these biotypes are not fully understood. We evaluated nutrient runoff quality for three tall fescue biotypes (common, high alkaloid endophyte [wild]; low alkaloid endophyte [novel]; and endophyte free [free]) under two fertilizer sources (broiler litter [BL] and inorganic fertilizer) in grazed systems and a hayed system with inorganic fertilization of endophyte free fescue. The seven treatments were replicated twice on 1 ha paddocks near Watkinsville, Georgia. Grazed paddocks were stocked in September each year with weaned Angus (Bos taurus) heifers (2002 to 2007) and steers (2008 to 2009) at rates of $\sim 3$ to 6 head paddock ${ }^{-1}$ adjusted every 28 days to maintain 1 to $3 \mathrm{Mg} \mathrm{ha}^{-1}$ of available forage. Weather conditions varied from very dry to very wet and allowed 15 grazing periods (50 to 198 days). Tall fescue with novel-endophyte association had lower or equal runoff concentrations and loads for inorganic nitrogen $(\mathrm{N})$, total $\mathrm{N}(\mathrm{TN})$, ortho-phosphorus (ortho-P), and total P (TP) than fescue with wild- or free-endophyte association (fescue treatment mean concentrations $\left[\mathrm{mg} \mathrm{L}^{-1}\right]:<0.8$ inorganic $\mathrm{N},<4.0 \mathrm{TN},<3.5$ ortho-P and TP; mean loads $\left[\mathrm{kg} \mathrm{ha}^{-1}\right]:<0.08$ inorganic $\mathrm{N},<0.40 \mathrm{TN},<0.30$ ortho-P and TP; all original untransformed data). This indicates increased adoption of novel-endophyte fescue, as previously recommended, presents no additional risk for nutrient losses regardless of fertilization source. Weather variability had impact on assessed variables. Mean total runoff across all paddocks during above average $(27.2 \%)$ and average $(20.6 \%)$ monthly rainfall periods were 15.2 - and 1.9-fold greater than that from the below average $(52.2 \%)$ monthly rainfall period. Nutrient loads also were greater: 3.4-fold (TP) to 14.6-fold (ammonium-N). Pollutant loads in the upper quartile were several fold greater than those from the rest of the data. The presence of cattle increased ortho-P load up to 3 -fold compared with periods with no cattle.
\end{abstract}

Key words: broiler litter — extreme rainfall—fescue toxicosis— grazing — livestock—water quality

Tall fescue (Lolium arundinaceum [Schreb.] S.J. Darbysh.) is a cool-season perennial forage grown on more than 15 million ha in the United States, primarily in the east-central, mid-southern, and the Pacific Northwest regions (Rogers and Locke 2013; Hoveland 2009; Hannaway et al. 2009). It establishes easily, tolerates variable soil and climatic conditions, and provides good forage availability (Belesky and West 2009; Fribourg et al. 2009), which reduces
The symbiosis enhances tall fescue tolerance to biotic and abiotic stresses, thus improving growth, reproduction, and persistence. However, the endophyte produces the ergot alkaloids peramine and loline (Rogers and Locke 2013), which reduce herbivory and adversely affect grazing animal performance and productivity, especially during spring and fall (fescue toxicosis) (Stuedemann and Hoveland 1988; Hill et al. 1994; Bouton et al. 2002; Hoveland 2009). Beef industry losses due to fescue toxicosis range from US $\$ 0.5$ to US $\$ 1$ billion annually (Rogers and Locke 2013; Gunter and Beck 2004).

Endophyte-free or novel nontoxic ergot alkaloid producing endophyte lines of tall fescue have been developed for grazing. Endophyte-free tall fescues have demonstrated low persistence (Waller 2009; Hopkins et al. 2009), while novel-endophyte tall fescues have demonstrated animal performance comparable to endophyte-free tall fescue and persistence comparable to wild-endophyte tall fescue (Bouton et al. 2002; Waller 2009; Belesky and West 2009). The first of the commercially available novel-endophyte biotypes, MaxQ, was a 'Jesup' tall fescue cultivar hosting a novel endophyte AR542 (Pennington Seed Co., Madison, Georgia) (Bouton et al. 2002).

Beef cattle production in the southeastern United States is typically located on less productive crop lands. Franzluebbers (2007) reported that $53 \%$ of farms in the region had cattle and $41 \%$ had pastures with a mean area of 30 ha. Many of these farms have a mixture of poultry (Gallus gallus domesticus) and beef cattle production. The combination is advantageous since the broiler litter (BL; $1.0 \mathrm{~kg} \mathrm{bird}^{-1}$ ) (Ritz and Merka 2013) can be applied to nearby pastures as fertilizer (more than $40 \%$ in Georgia), or sold (Starkey 2003).

Dinku M. Endale (corresponding author) is an agricultural engineer with the USDA Agricultural Research Service (ARS), Tifton, Georgia. Harry H. Schomberg is an ecologist with the USDA ARS, Beltsville, Maryland. Alan J. Franzluebbers is an ecologist with the USDA ARS, Raleigh, North Carolina. Dwight S. Seman is a retired animal scientist with the USDA ARS, Lexington, Kentucky. Dorcas H. Franklin is an associate professor with the University of Georgia, Crop and Soil Sciences Department, Athens, Georgia. John A. Stuedemann was a retired animal scientist (deceased) at the USDA ARS, J. Phil Campbell Sr. Natural Resource Conservation Center, Watkinsville, Georgia.

Received September 10, 2019; Revised April 14, 2020; Accepted April 15, 2020. 


\section{Figure 1}

Paddock layout and designation at Dawson Field, Watkinsville, Georgia.
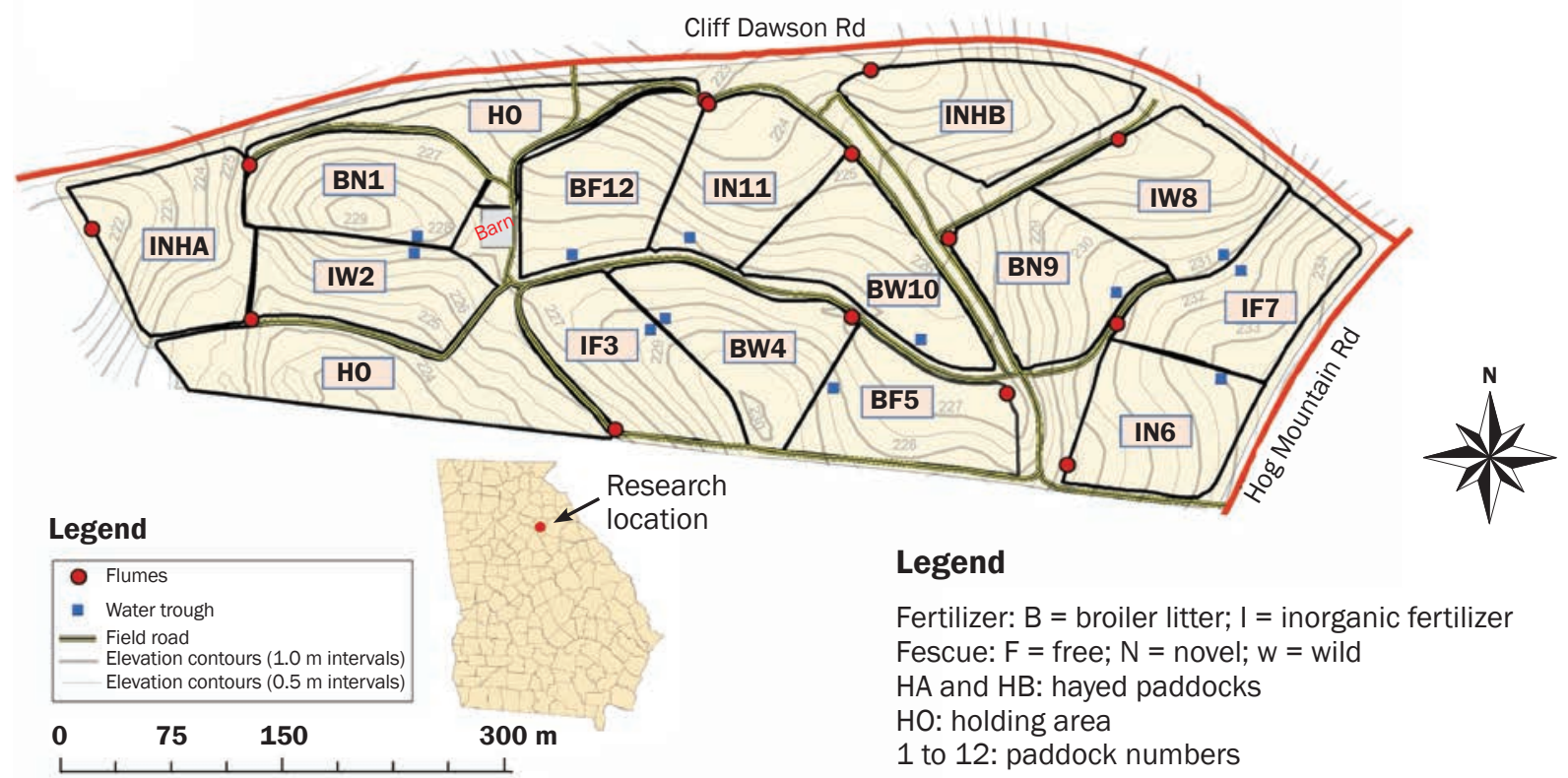
Legend
Fertilizer: $\mathrm{B}=$ broiler litter; $\mathrm{I}$ = inorganic fertilizer
Fescue: $F=$ free; $N=$ novel; $w=$ wild
$\mathrm{HA}$ and $\mathrm{HB}$ : hayed paddocks
$\mathrm{HO}$ : holding area
1 to 12 : paddock numbers

Repeated application of $\mathrm{BL}$ on pastures can lead to excessive loading of nutrients, which, along with the relatively high annual rainfall and high runoff potential across the southeastern United States, $(\sim 1,250 \mathrm{~mm})$ raises concern about edge-of-pasture sediment and nutrient losses contributing to water quality impairment (Phillip et al. 2015).

Pasture renovation to improve forage availability creates an opportunity to consider new tall fescue biotypes, but the selection presents the following economic and sustainability issues: (1) wild-endophyte associated tall fescue provides excellent stand persistence, but periodic poor animal performance; (2) endophyte-free tall fescue produces excellent animal performance, but potentially has poor stand persistence; and (3) novel-endophyte fescue promises good stand persistence and excellent animal performance, but has substantially higher seed cost.

The fescue-endophyte association also has ecological impacts related to organic carbon (C) inputs affecting soil quality, nutrient cycling, surface and subsurface hydrologic ramifications, water quality, etc. In a meta-analysis on how grass-endophyte symbiosis affects subsurface soil processes and ecosystem services, Omacini et al. (2012) found significant changes in root biomass, root exudates, and mycorrhizal colonization of endophyte infected plants compared with noninfected comparative pairs. No pattern in the response of soil fauna to endophyte infection was identified and no significant change was detected in the rate of processes like soil microbial respiration and litter decomposition. Effects on other processes like nutrient mineralization/cycling, nitrogen $(\mathrm{N})$ fixation, contribution of bacteria and fungi to soil activity, etc., could not be assessed due to limited empirical data.

Fescue endophyte association's impact on cattle grazing behavior can result in alteration of surface soil properties, the distribution of soil organic C and total N, and creation of areas of soil compaction within pastures. Cattle in endophyte-infected tall fescue with high alkaloid production spend less time grazing and more time under shades and near water sources in environmentally stressful periods such as high temperatures (Stuedemann and Hoveland 1988). Given the choice, cattle show grazing preference of tall fescue free of endophyte or of low alkaloid. The true hydrologic responses of pastures under these myriad possible variabilities have not been well elucidated.

Our objective here is to present results from a long-term grazing study on the influence of three management factors: (1) fescue-endophyte associations, (2) fertilizer source, and (3) forage management on fieldscale runoff nutrient quality. Extended wet and dry periods during the study provided additional opportunity to assess impacts of variable weather on nutrient. Franzluebbers and Stuedemann (2006) and Franzluebbers et al. $(2009,2012 \mathrm{a})$ previously presented results from this field-scale study on animal performance, plant stand, and soil quality aspects of managing wild-, novel-, and endophyte-free tall fescue as a function of fertilization and harvest management, while Endale et al. (2013) presented an analysis of treatment effects on runoff.

\section{Materials and Methods}

Site Description. The approximately 20 ha experimental site in the Southern Piedmont

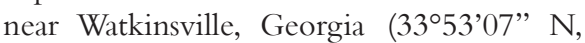
$83^{\circ} 26^{\prime} 04^{\prime \prime}$ W), was transitioned for the research between 1998 and 2002 (Dawson Field; figure 1). For about 10 years before beginning the research, the field was maintained as naturalized herbaceous fallow with periodic mowing. Prior to 1988 the area was cropped to corn (Zea mays L.), cotton (Gossypium hirsutum L.), and soybeans (Glycine max) using conventional tillage for several decades by a local producer. As described in Endale et al. (2013), paddock attributes of surface area, area of slope class of $1 \%$ to $9 \%$ in increments of $1 \%$, cumulative percentage area up to each slope class, area weighted slope (3.3\% to $4.8 \%)$, length of each 
of five orders of runoff flow paths (analogous to stream orders), and total flow path length $(1,337$ to $3,692 \mathrm{~m})$ were determined based on analysis at $0.1 \mathrm{~m}$ cell resolution using global positioning and geographic information system. A survey in early- to mid-1980s established the soil series as predominantly $(\sim 80 \%)$ Cecil, a series that covers almost half of the Southern Piedmont, with 12\% Pacolet and 8\% Appling (all fine, kaolinitic, thermic Typic Kanhapludults) (unpublished data). Surface texture is sandy loam to sandy clay loam underlain by a clayey Bt horizon over a loamy saprolite $\mathrm{C}$ horizon. The soil is well drained, moderately permeable, and deep unless located at eroded landscape positions. Long-term (1937 to 2011; http://www. ncdc.noaa.gov ; http://georgiaweather.net) mean annual rainfall was $1,240 \mathrm{~mm}$ with long-term monthly means varying from $79 \mathrm{~mm}$ in October to $136 \mathrm{~mm}$ in March. Despite the high mean annual rainfall, periods of drought are common (Endale et al. 2011). Mean annual temperature is $16.5^{\circ} \mathrm{C}$.

Experimental Design. The primary study objectives focused on productivity and persistence of tall fescue-endophyte associations, animal performance, soil quality, and hydrology. Availability of land, animal resources, and long-term funding challenges led to design compromises that limited the study to two replications per treatment. Fourteen $1.00 \pm$ 0.05 ha grazing paddocks, large enough to allow multiple head of beef cattle to graze, were established and equipped for hydrologic monitoring and sampling. Topographic characteristics of paddocks and their effects on runoff was presented by Endale et al. (2013).

The experiment was laid out as a randomized block design with three levels of fescue-endophyte association (wild, novel, and free; producing high, low, and zero ergot alkaloids, respectively) and two sources of nutrients (BL and inorganic fertilizer) (six treatments; figure 1). Two paddocks were maintained for haying (treatment no. 7) to compare with the corresponding grazed treatment with novel-endophyte fescue and inorganic fertilizer. Inorganic fertilizer and BL were applied as split applications in early fall and late winter (September/October and February/March). Broiler litter for the duration of the study came from several broiler houses managed similarly by a nearby poultry producer.

Grazing began in April of 2002 using weaned Angus heifers (2002 to 2007) and steers (2008 to 2009) at a variable stocking rate of $\sim 3$ to $6 \mathrm{head} \mathrm{ha}^{-1}$. Stocking (other than the first year) was in September, and rate was adjusted every 28 days to maintain 1 to $3 \mathrm{Mg}$ $\mathrm{ha}^{-1}$ of available forage per paddock. Weather conditions influencing soil water and forage production dictated when cattle were stocked and removed. During periods when estimated forage biomass fell $<1 \mathrm{Mg} \mathrm{ha}^{-1}$ for most paddocks, cattle were moved to a nearby holding area of endophyte-free fescue and supplemented with hay until sufficient forage regrowth occurred ( 1 to $3 \mathrm{Mg} \mathrm{ha}^{-1}$ ) to allow restocking. Herd size across paddocks varied between 39 and 66 animals. Fescue was cut and baled in hayed paddocks two to three times a year whenever forage mass accumulated above $1 \mathrm{Mg} \mathrm{ha}^{-1}$. Paddocks were occasionally mowed in late spring to remove aboveground weed reproductive structures. The study concluded in April of 2010.

Data collected on animal grazing patterns and performance included grazing period (total of 15), start and finish dates of each grazing period, days per grazing period, and animal numbers per grazing period (tables 1 and 2). In each paddock, individual animal weights determined every 28 days were used to compute animal units. One animal unit, equivalent to $454 \mathrm{~kg}$ of live animal weight, provides a convenient normalized measure across different types of livestock (Kellogg et al. 2014). Animal units were used to estimate wet manure mass and wet manure $\mathrm{N}$ and phosphorus $(\mathrm{P})$ contents using coefficients from Kellogg et al. (2014). The given coefficients for pastured beef calves, heifers, cows, bulls, and stockers and grass-fed are $10.61 \mathrm{t}$ of manure as excreted per animal unit per year as wet weight; $5.44 \mathrm{~kg}$ of $\mathrm{N}$ per wet tonne manure weight; and $2.26 \mathrm{~kg}$ of $\mathrm{P}$ per wet tonne manure weight. Nitrogen and $\mathrm{P}$ are considered in elemental forms and include those in urine. Number of runoff events during grazing, days with and without cattle before runoff, and animal units before runoff were compiled. Fertilizer management variables included days from $\mathrm{N}$ and $\mathrm{P}$ fertilization to a subsequent runoff event and amount of $\mathrm{N}$ and $\mathrm{P}$ fertilization immediately preceding a runoff event. (See table 3 for a complete list of variables.) The statistical methodology described below highlights how these data were used in the analyses.

Runoff, Sample Collection and Processing, and Analyses. Rainfall amounts for five-minute periods were measured near Paddock BW10 (figure 1) with a tipping bucket gauge (Model TR-525M, Texas Electronics, Dallas, Texas) and stored in a Campbell Scientific CR10X data logger (Logan, Utah). Surface runoff was measured at the lowest point (outlet) of each paddock using a combination of a $0.46 \mathrm{~m} \mathrm{H}$ flume (Brakensiek et al. 1979) and a 17.24 $\mathrm{kPa}$ flow depth sensing transducer (Druck, New Fairfield, Connecticut) positioned in

\section{Table 1}

Grazing period start and end dates, grazing days, and number of runoff events during each of 15 grazing periods.

\begin{tabular}{lllcc}
\hline Period \# & Beginning date & Ending date & No. of days* & Runoff events \\
\hline 1 & Apr. 11, 2002 & May 30, 2002 & 50 & 1 \\
2 & Oct. 1, 2002 & Dec. 10, 2002 & 71 & 3 \\
3 & Mar. 13, 2003 & Sept. 25, 2003 & 197 & 11 \\
4 & Nov. 18, 2003 & Jan. 29, 2004 & 73 & 1 \\
5 & Mar. 18, 2004 & Sept. 30, 2004 & 197 & 6 \\
6 & Oct. 19, 2004 & Jan. 11, 2005 & 85 & 1 \\
7 & Apr. 7, 2005 & Oct. 21, 2005 & 198 & 4 \\
8 & Nov. 10, 2005 & Jan. 5, 2006 & 57 & 1 \\
9 & Mar. 23, 2006 & June 22, 2006 & 92 & 0 \\
10 & Oct. 5, 2006 & Feb. 2, 2007 & 121 & 3 \\
11 & Apr. 3, 2007 & June 14, 2007 & 73 & 0 \\
12 & Oct. 16, 2007 & Dec. 11, 2007 & 57 & 0 \\
13 & Mar. 27, 2008 & Aug. 14, 2008 & 141 & 0 \\
14 & Oct. 28, 2008 & Jan. 7, 2009 & 72 & 2 \\
15 & Apr. 2, 2009 & July 7, 2009 & 97 & 2 \\
\hline
\end{tabular}

*No. of days: mean \pm SE $105.4 \pm 13.7$; median 85.0; total 1,581. 
Table 2

Descriptive statistics for animal-related variables during 15 grazing periods from April of 2002 to July of 2009.

\begin{tabular}{|c|c|c|c|c|c|c|c|}
\hline \multirow[b]{4}{*}{ Variable } & \multirow[b]{4}{*}{ Statistics* } & \multicolumn{3}{|l|}{ Organic } & \multicolumn{3}{|l|}{ Inorganic } \\
\hline & & \multirow{2}{*}{$\begin{array}{l}\text { Novel } \\
1 \text { and } 9\end{array}$} & \multirow{2}{*}{$\frac{\text { Wild }}{4 \text { and } 10}$} & \multirow{2}{*}{$\begin{array}{l}\text { Free } \\
5 \text { and } 12 \\
\end{array}$} & \multirow{2}{*}{$\frac{\text { Novel }}{6 \text { and } 11}$} & \multirow{2}{*}{$\begin{array}{l}\text { Wild } \\
2 \text { and } 8\end{array}$} & \multirow{2}{*}{$\begin{array}{l}\text { Free } \\
3 \text { and } 7\end{array}$} \\
\hline & & & & & & & \\
\hline & & 1 & 2 & 3 & 4 & 5 & 6 \\
\hline \multirow[t]{6}{*}{ Grazing animal numbers (GAN) } & Mean & 352.8 & 444.4 & 350.3 & 350.6 & 481.8 & 349.3 \\
\hline & SE & 30.4 & 43.7 & 32.4 & 33.1 & 52.1 & 31.8 \\
\hline & Median & 289.0 & 377.5 & 291.0 & 283.0 & 363.0 & 286.5 \\
\hline & Minimum & 146.0 & 171.0 & 160.0 & 171.0 & 187.0 & 160.0 \\
\hline & Maximum & 650.0 & 934.0 & 706.0 & 760.0 & 1217.0 & 760.0 \\
\hline & Total & $10,585.0$ & $13,331.0$ & $10,510.0$ & $10,517.0$ & $14,454.0$ & $10,479.0$ \\
\hline \multirow[t]{6}{*}{ Grazing animal unit (GAU) } & Mean & 226.3 & 267.3 & 225.9 & 224.3 & 281.6 & 224.0 \\
\hline & SE & 24.8 & 31.0 & 27.2 & 25.7 & 34.8 & 25.3 \\
\hline & Median & 165.6 & 189.3 & 155.7 & 160.7 & 194.5 & 157.4 \\
\hline & Minimum & 69.2 & 77.4 & 79.4 & 95.6 & 105.6 & 80.5 \\
\hline & Maximum & 496.5 & 658.1 & 531.3 & 524.6 & 787.3 & 509.7 \\
\hline & Total & $6,789.1$ & $8,018.5$ & $6,778.1$ & $6,728.8$ & $8,449.0$ & $6,720.7$ \\
\hline \multirow[t]{6}{*}{ Wet manure weight (Mg) } & Mean & 6.6 & 7.8 & 6.6 & 6.5 & 8.2 & 6.5 \\
\hline & SE & 0.7 & 0.9 & 0.8 & 0.7 & 1.0 & 0.7 \\
\hline & Median & 4.8 & 5.5 & 4.5 & 4.7 & 5.7 & 4.6 \\
\hline & Minimum & 2.0 & 2.3 & 2.3 & 2.8 & 3.1 & 2.3 \\
\hline & Maximum & 14.4 & 19.1 & 15.4 & 15.3 & 22.9 & 14.8 \\
\hline & Total & 197.4 & 233.2 & 197.1 & 195.7 & 245.7 & 195.4 \\
\hline \multirow[t]{6}{*}{ Wet manure elemental $\mathrm{N}$ weight (kg) (MAN) } & Mean & 39.5 & 46.6 & 39.4 & 39.1 & 49.1 & 39.1 \\
\hline & SE & 4.3 & 5.4 & 4.7 & 4.5 & 6.1 & 4.4 \\
\hline & Median & 28.9 & 33.0 & 27.2 & 28.0 & 33.9 & 27.5 \\
\hline & Minimum & 12.1 & 13.5 & 13.9 & 16.7 & 18.4 & 14.0 \\
\hline & Maximum & 86.6 & 114.8 & 92.7 & 91.5 & 137.4 & 88.9 \\
\hline & Total & $1,184.6$ & $1,399.0$ & $1,182.6$ & $1,174.0$ & $1,474.2$ & $1,172.6$ \\
\hline \multirow[t]{6}{*}{ Wet manure elemental P weight (kg) (MAP) } & Mean & 16.5 & 19.4 & 16.4 & 16.3 & 20.5 & 16.3 \\
\hline & SE & 1.8 & 2.3 & 2.0 & 1.9 & 2.5 & 1.8 \\
\hline & Median & 12.0 & 13.8 & 11.3 & 11.7 & 14.1 & 11.4 \\
\hline & Minimum & 5.0 & 5.6 & 5.8 & 7.0 & 7.7 & 5.9 \\
\hline & Maximum & 36.1 & 47.8 & 38.6 & 38.1 & 57.2 & 37.1 \\
\hline & Total & 493.6 & 582.9 & 492.8 & 489.2 & 614.2 & 488.6 \\
\hline
\end{tabular}

Note: Treatment no. 7 was the hayed only treatment with novel endophyte and inorganic fertilizer. Fertilizer $=$ organic and inorganic. Fescue $=$ novel,

wild, and free. Paddocks = 1 through 12. Treatment no. = 1 through 6. SE = standard error.

*Statistics are based on 30 observations per treatment (2 paddocks and 15 grazing periods).

the flume stilling well and connected to a data logger. Five-minute average flow depth and flow rate, based on the flume calibration curve (Bos 1978), were used to determine event runoff characteristic throughout the eight-year study period. Endale et al. (2013) performed Principal Component (PC) analysis using 23 variables describing rainfall, runoff, and landscape attributes (see site description above), and identified event rainfall amount, length of flow path order 1, cumulative percentage area up to slope class $2 \%$, and area-weighted slope as the best variables to account for the effects of landscape on runoff variability.
Runoff samples were collected using a 2.5 $\mathrm{cm}$ diameter polyvinyl chloride (PVC) pipe securely attached below the outlet of each flume. The pipe had $1.6 \mathrm{~mm}$ diameter holes drilled at $2.5 \mathrm{~cm}$ spacing along its length. It was placed at a slight angle centered on the outflow path to continuously intercept and direct part of the runoff to a $15 \mathrm{~cm}$ diameter PVC pipe located to one side of the flume outlet. The $15 \mathrm{~cm}$ pipe was sealed at the bottom with a PVC cap, and for protection, housed inside a $20 \mathrm{~cm}$ diameter PVC pipe capped at the top and bottom. Runoff samples were removed from the field within 24 hours of a rainfall event. They were placed on ice in coolers and transported to the labora- tory $\sim 2.5 \mathrm{~km}$ away where they were stored at $4^{\circ} \mathrm{C}$. Within 24 hours, a $50 \mathrm{~mL}$ subsample was filtered through a preweighed 0.45 micron cellulose-nitrate-acetate membrane. A second $50 \mathrm{~mL}$ unfiltered sample was also saved. Filtered and unfiltered subsamples were kept frozen until analyzed. Unfiltered samples were acidified with hydrogen chloride $(\mathrm{HCl})$.

Filtered samples were analyzed on a Technicon Autoanalyzer II (SEAL Analytical, Mequon, Wisconsin) for dissolved ammonium-N $\left(\mathrm{NH}_{4}-\mathrm{N}\right)$ using the salicylate-hypochlorite method (Crooke and Simpson 1971) and nitrate- $\mathrm{N}\left(\mathrm{NO}_{3}-\mathrm{N}\right)$ by the Griess-Ilosvay method (Keeney and 


\section{Table 3}

List of covariates and nutrient concentration and load abbreviations.

\begin{tabular}{|c|c|c|c|c|}
\hline Covariate* & ID & $\begin{array}{l}\text { Nutrient concentration } \\
\text { and load }\end{array}$ & ID & Obst \\
\hline $\begin{array}{l}\text { Amount nearest N-FERT } \\
\text { to runoff }\end{array}$ & ANF & Ammonium- $\mathrm{N}$ concentration & AMC & 731 \\
\hline $\begin{array}{l}\text { Amount nearest P-FERT } \\
\text { to runoff }\end{array}$ & APF & Ammonium-N load & AML & 733 \\
\hline Days grazed before runoff $\ddagger$ & DGZ & & & \\
\hline $\begin{array}{l}\text { Days from runoff to } \\
\text { nearest N-FERT }\end{array}$ & DNF & Nitrate-N concentration & NTC & 731 \\
\hline $\begin{array}{l}\text { Days from runoff to } \\
\text { nearest P-FERT }\end{array}$ & DPF & Nitrate-N load & NTL & 739 \\
\hline Days since last runoff & DSLR & Ortho-P concentration & OPC & 721 \\
\hline Days with cattle before runoff & DWC & Ortho-P load & OPL & 725 \\
\hline $\begin{array}{l}\text { Days without cattle } \\
\text { before runoff }\end{array}$ & DWOC & Total $\mathrm{N}$ concentration & TNC & 266 \\
\hline Grazing animal unit & GAU & Total N load & TNL & 266 \\
\hline Grazing during runoff & GCDR & Total P concentration & TPC & 266 \\
\hline Precipitation amount (mm) & PAM & Total P load & TPL & 267 \\
\hline Precipitation duration (h) & PDU & & & \\
\hline Precipitation intensity & PIN & & & \\
\hline Runoff date & ROD & & & \\
\hline Runoff volume & ROV & & & \\
\hline \multicolumn{5}{|c|}{ *N-FERT and P-FERT signify nitrogen (N) and phosphorus (P) fertilization, respectively. } \\
\hline \multicolumn{5}{|c|}{$\begin{array}{l}\text { tObs is the number of observations in the analysis data set. Data for total concentration and } \\
\text { load came from } 2007 \text { through the end of the project period only. }\end{array}$} \\
\hline \multicolumn{5}{|c|}{$\begin{array}{l}\text { Ilf cattle are present during runoff, then DGZ equals days from start of grazing to runoff. If cattle } \\
\text { are absent during runoff, then it equals days grazed during the grazing period immediately pre- } \\
\text { ceding runoff. }\end{array}$} \\
\hline
\end{tabular}

Nelson 1982) after reduction of $\mathrm{NO}_{3}{ }^{-}$with a cadmium (Cd) column. Filtered samples were analyzed for soluble P (ortho-P) by the molybdate blue method (Murphy and Riley 1962). Total P (TP) and total N (TN) of unfiltered samples were determined colorimetrically as above following digestion by the alkaline persulfate oxidation technique (Franson 1998a,1998b). Data for TN and TP are available only from events in 2007 and later due to logistical issues associated with analysis of earlier samples. Nutrient loads were calculated by multiplying the nutrient concentration by the runoff volume for an event and correcting for differences in paddock areas (divided by the paddock area). Additional details about methods and materials are available in Endale et al. (2013), Franzluebbers et al. (2009, 2012a), and Franzluebbers and Stuedemann (2006).

Statistical Analysis. Over the eight-year period, 77 runoff events were recorded from one or more paddocks (Endale et al. 2013). Paddocks with zero runoff were excluded from the analyses. Due to limited runoff volume for some samples, analysis for the complete suite of nutrients was not possible. The number of observations for each nutrient concentration and load is available in table 3. Statistical analyses of the data considered two cohorts. The first included all useable data. The second cohort consisted of only the observations in the upper quartile, representing those events with large concentrations or large loads. In selecting the second cohort for each nutrient, the upper quartile for each paddock was identified and combined with selections from the other paddocks for subsequent analysis.

Statistical analyses were conducted using SAS ver. 9.4 within SAS Enterprise Guide ver. 7.1 (SAS Inst. 2014). Like the approach taken in the analyses of treatment effects on water runoff (Endale et al. 2013), we identified a set of nontreatment variables that could affect runoff nutrient concentration and load (listed in table 3 under the covariate column heading) for a total of 15 variables. Principal component analysis of these variables was conducted using method PRIN in PROC FACTOR of SAS. Results of the varimax rotation (results not shown) identi- fied five PCs with Eigen values $>1$. Variable loadings on the PCs related to grazing animal units, days since nutrient application, amount of nutrient applied immediately before runoff events, runoff volume, and precipitation characteristics. Scores estimated for the five PCs were used as covariates in the analysis of variance to evaluate treatment effects.

The SAS MIXED procedure was used for analysis of variance. Nutrient concentration and load data were transformed to natural logarithms +1 prior to analysis. To facilitate analysis of the unbalanced experimental factors, treatment combinations were coded 1 through 7 (table 2). Treatment and PC scores were considered fixed effects. Block (replicate) was considered a random effect. Runoff events over time were repeated effects with subjects identified as the individual paddocks. A spatial exponential covariance structure was used because runoff events occurred at unevenly spaced time intervals. Specific treatment effects were determined from a piori constructed contrasts using LSMESTIMATE statements. Least square treatment means and upper and lower 95\% confidence limits were determined within the LSMEANS and LSMESTIMATE statements and were back transformed for presentation in data tables.

The repeated measures analysis provided an indication of the annualized loss of nutrients associated with management treatments. The long-term nature of the data set provided an indication of management influences on median losses of nutrients. Because of the inherent variability associated with rainfall events, field topography, and grazing animal behavior along with the limitation of having only two replications, we chose to consider differences significant at $\alpha \leq 0.10$.

\section{Results and Discussion}

Rainfall Variability and Impact on Runoff and Runoff Nutrient Loss. Endale et al. (2011) previously presented an analysis of the impact of rainfall on runoff in this study. A summary of their results illustrating the prominent sustained drought and wet periods is presented here. The 12-month running average rainfall deviation from the long-term annual average is shown in figure 2. Comparing the 30 months of positive deviation versus the 63 months of negative deviation (April of 2002 to December of 2009), for all paddocks total runoff was 2.1 times greater $(4,631 \mathrm{~mm}$ and $2,127 \mathrm{~mm}$, respectively), total ortho-P load was $\sim 1.7$ times greater, total $\mathrm{NH}_{4}-\mathrm{N}$ load 


\section{Figure 2}

Deviation of the 12 months running average rainfall during the study from the 74-year (1937 to 2010) annual average of $1,240 \mathrm{~mm}$ near Watkinsville, Georgia.

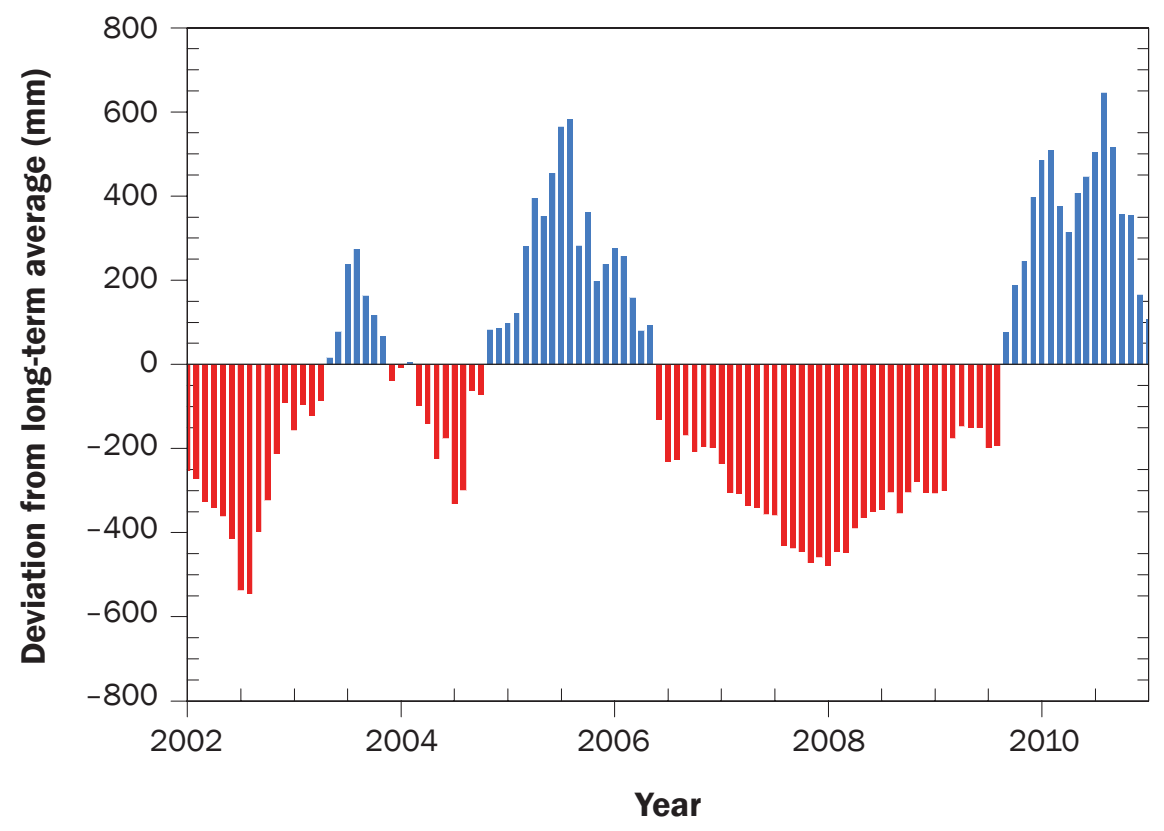

was about the same, and total $\mathrm{NO}_{3}^{-}$load was $\sim 2.9$ times lower (data not shown).

Individual monthly rainfall varied from below to above long-term monthly averages and are more directly related to runoff generation and nutrient losses. Supplementary tables S1 and S2 summarize runoff and runoff nutrient losses from May of 2002 (first month of runoff data) through December of 2009 for periods of monthly rainfall below average, average, and above average (52\%, $21 \%$, and $27.2 \%$ of the time, respectively). Monthly mean rainfall for above average and average periods was 3.1 and 1.6 times that of the below average period $(183.5,96.5$, and $60.1 \mathrm{~mm}$, respectively). Mean total runoff during above and average periods were 15.2 and 1.9 times that of the below average period (15.99, 2.02, and $1.06 \mathrm{~mm} \mathrm{ha}^{-1}$, respectively). Across all paddocks, total nutrient loads were 3.4-fold (TP) to 14.6-fold $\left(\mathrm{NH}_{4}-\mathrm{N}\right)$ greater from the above average than the below average period. See Supplemental table S2 for more details.

Grazing Activity. Cattle grazed during 15 periods from April of 2002 to July of 2009 and grazing days per period varied from 50 to 198 (mean 105.4 $\pm 13.7 \mathrm{SE}$; table 1 ). Runoff events occurred in 11 grazing periods, with 1 to 4 events per period except for period 3 in 2003 with 11 and period 5 in 2004 with 6 runoff events. Descriptive sta- tistics for grazing animal number, grazing animal unit, estimated wet manure weight, and wet manure elemental $\mathrm{N}$ and $\mathrm{P}$ weights for the 15 grazing periods are given in table 2. Refer to figure 1 and table 2 for details.

Overall Assessment of Water Quality. In this section, we present numerical comparisons for concentrations and loads related to presence and absence of cattle and upper quartile versus rest of the data using the original untransformed data. Loads are given in units of kilogram per hectare here and in cited supplementary material, whereas in figures and for statistical comparisons and summaries (treatment comparisons, see further below) units of gram per hectare are used. Figure 3 shows the overall distribution of nutrient concentrations (untransformed data) from the seven treatments over the study period. Supplementary table S3 gives summary statistics for nutrient concentrations and loads based on untransformed data, parsed into periods with and without cattle as well as all periods. Mean concentrations $\left(\mathrm{mg} \mathrm{L}^{-1}\right)$ with cattle were 1.3- to 7.3-fold greater than those without cattle for $\mathrm{NO}_{3}-\mathrm{N}$ (0.29 to 1.03 versus 0.08 to 0.26$) ; 1.5-$ to 2.3-fold greater for ortho-P (1.32 to 3.46 versus 0.72 to 2.57$) ; 1.1$ - to 1.9 -fold greater for TP (1.42 to 4.77 versus 1.13 to 3.06 ); and up to 1.8 times greater for TN (3.63 to 6.06 versus 2.48 to 3.34 ). For $\mathrm{NH}_{4}-\mathrm{N}$, concentra- tion was less from periods with cattle than without except for free fescue with inorganic fertilizer (4.2-fold greater) and wild fescue with BL fertilization (1.2-fold greater).

Total load $\left(\mathrm{kg} \mathrm{ha}^{-1}\right)$ (figure 4 , shown as $\mathrm{g}$ $\mathrm{ha}^{-1}$ ) was greater with than without cattle for $\mathrm{NO}_{3}-\mathrm{N}$ (up to 5.2 -fold; 0.24 to 4.43 versus 0.15 to 0.2 .44) and for ortho-P (up to 2.1fold; 5.12 to 16.36 versus 3.38 to 12.12 ). Total $\mathrm{NH}_{4}-\mathrm{N}$ load was up to 3.0-fold greater but only in BL treatments ( 1.78 versus 0.78$)$; in inorganic fertilizer treatments, load with cattle was $\sim 0.27$ that of without cattle. For TN and TP total load with cattle was $\sim 0.03$ that without cattle; a factor affecting this is that more of the data came from periods with no cattle $(n=22$ to 36$)$ than with cattle $(n=4$ to 9). Refer to supplementary table S3 for additional details.

Comparisons of concentration and load between the upper quartile and those in the rest of the data showed the following (data not presented). In grazed treatments, upper quartile mean concentrations $\left(\mathrm{mg} \mathrm{L}^{-1}\right)$ were greater by $10-$ to 31 -fold for $\mathrm{NO}_{3}-\mathrm{N}(0.60$ to 2.08 versus $<0.09$ ); 13 - to 28 -fold for $\mathrm{NH}_{4}-\mathrm{N}(1.44$ to 2.61 versus $<0.15) ; 2.9$ - to 3.9-fold for ortho-P (2.28 to 6.25 versus $<2.10$ ); 2.2 - to 3.0 -fold for TN (4.70 to 7.61 versus $<2.60$ ); and 3.0 - to 4.3 -fold for TP (2.65 to 6.86 versus <2.20). For hayed treatments differences were 39.1-fold for $\mathrm{NO}_{3}-\mathrm{N}, 27.8$-fold for $\mathrm{NH}_{4}-\mathrm{N}, 5.3$-fold for ortho-P, and $\sim 3.8$-fold for TN and TP with concentrations $<2.0$. Total loads in grazed treatments $\left(\mathrm{kg} \mathrm{ha}^{-1}\right)$ in the upper quartile were greater by 4.7- to 10.8 -fold for $\mathrm{NO}_{3}-\mathrm{N}$ for all but wild fescue with inorganic fertilization $(0.43$ to 2.66 versus $<0.15)$; 3.6 - to 12.1-fold for $\mathrm{NH}_{4}-\mathrm{N}$ (1.35 to 4.69 versus $<0.60)$; 3.2 - to 6.8 -fold for ortho-P $(8.56$ to 22.30 versus $<6.20$ ); 2.0 - to 3.0 - fold for TN (4.56 to 9.76 versus $<3.60$ ); and $2.4-$ to 4.2-fold for TP (2.67 to 5.28 versus $<1.50$ ). For hayed treatment, mean loads for upper quartile data were greater compared with means for the rest of the data up to 15 -fold for ortho-P, TN, and TP, 56-fold for $\mathrm{NH}_{4}-\mathrm{N}$ and 177-fold for $\mathrm{NO}_{3}-\mathrm{N}$ with loads of 1.71 to $9.02 \mathrm{~kg} \mathrm{ha}^{-1}$ for the upper quartile and $<2.40 \mathrm{~kg} \mathrm{ha}^{-1}$ from the rest.

Supplementary tables S4 and S5 give breakdown of annual load estimates. Total loads $\left(\mathrm{kg} \mathrm{ha}^{-1}\right)$ across the study period were numerically greater from organic fertilizer (BL) treatments than inorganic treatments for ortho-P (2.0-fold; 69.8 versus 35.8), TP (1.3- 


\section{Figure 3}

Box plots showing distribution of untransformed nutrient concentration over the study period ([a] nitrate-nitrogen [ $\left.\mathrm{NO}_{3}-\mathrm{N}\right]$, [b] ammonium- $\mathrm{N}$ [NH ${ }_{4}^{-}$ N], [c] total N [TN], [d] ortho-phosphorus [ortho-P], and [e] total P [TP]). Solid lines within boxes represent medians. Samples for TN and TP came from 2007 to 2009 only.

(a)

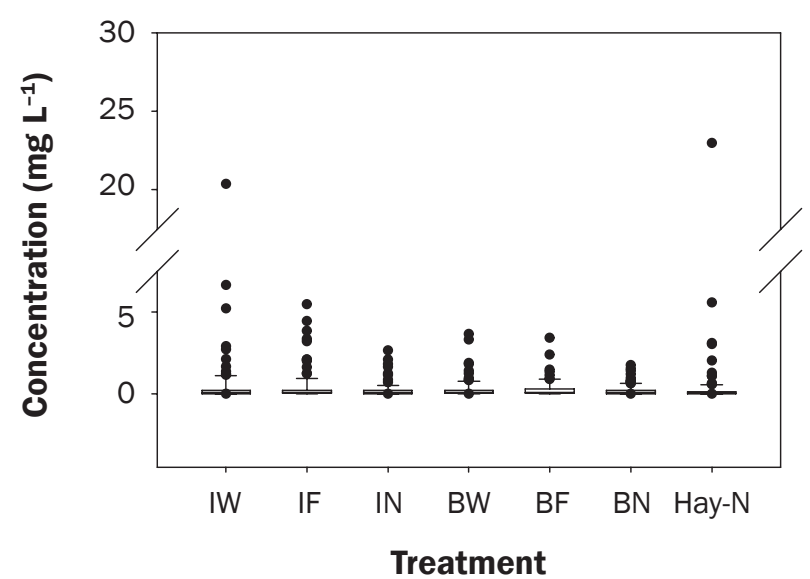

(c)

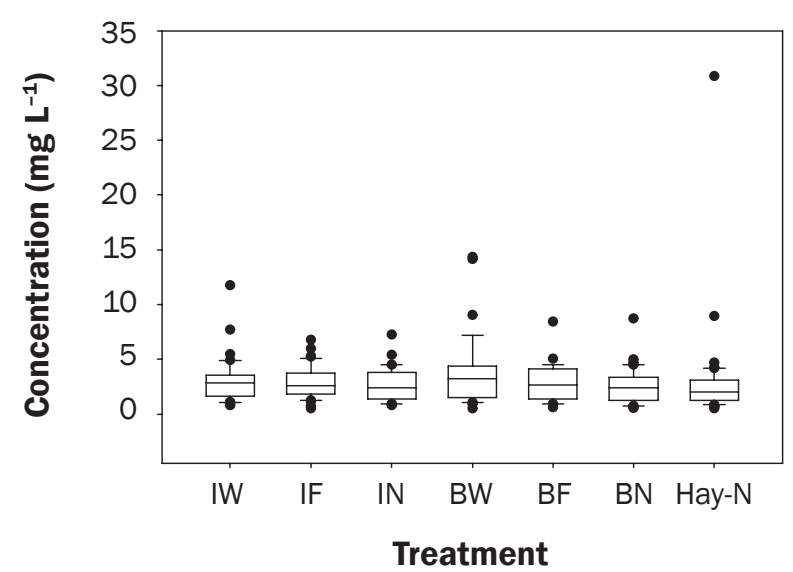

(e)

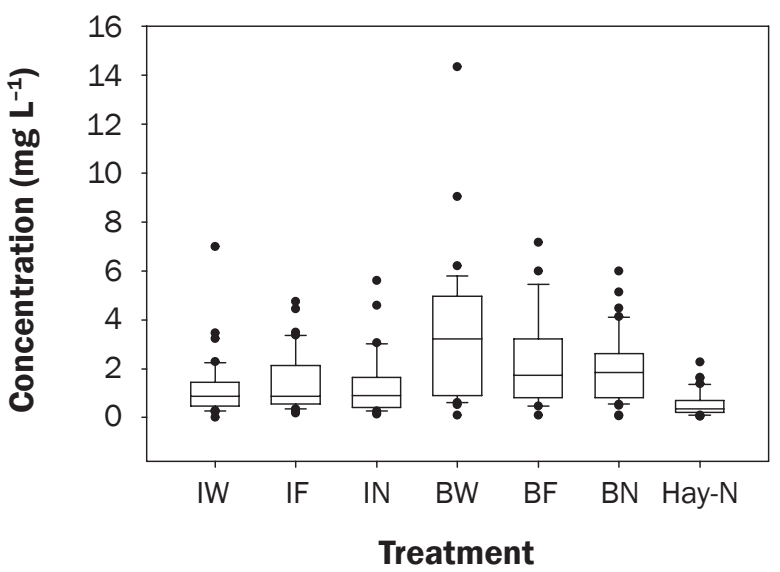

(b)

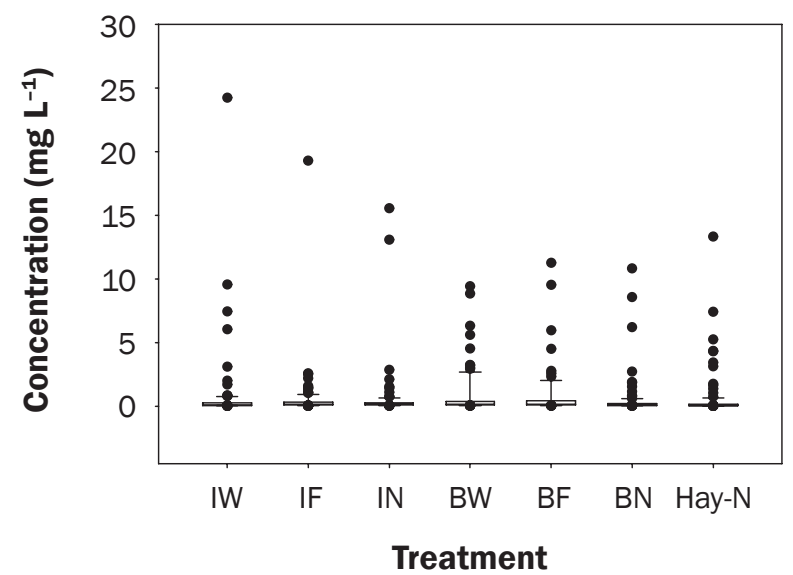

(d)

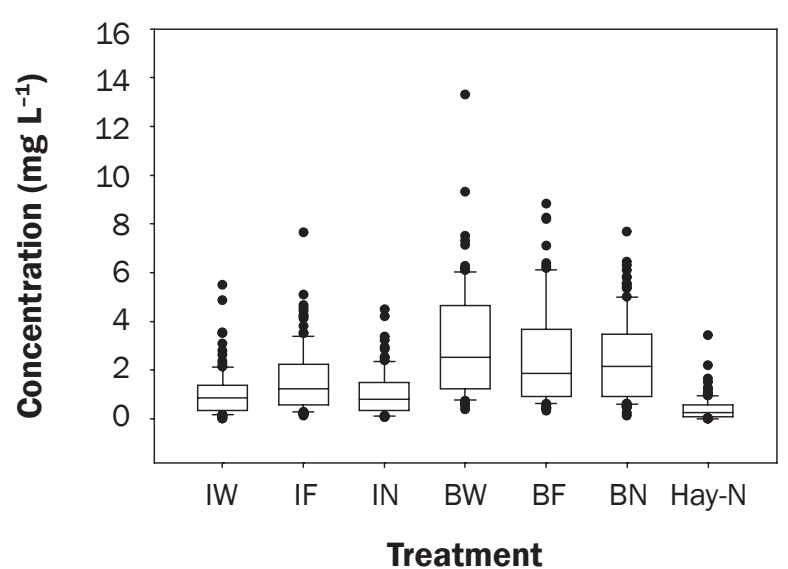

Legend

Treatment

Grazed

Fertilizer

I = inorganic fertilizer

Fescue-endophyte association

$W=$ wild

$F=$ free

$\mathrm{N}=$ novel

Hayed

Hay- $\mathrm{N}=$ hayed with novel-endophyte fescue fold; 19.8 versus 15.3), and $\mathrm{NH}_{4}-\mathrm{N}$ (1.4-fold; 10.6 versus 7.6). In a reversal, total loads for $\mathrm{NO}_{3}-\mathrm{N}$ and $\mathrm{TN}$ were numerically greater from inorganic than organic fertilizer treat- ments (3.5- and 1.4-fold, respectively; 11.2 versus 3.2 and 33.9 versus 23.6, respectively). Across all treatments and years total load $(\mathrm{kg}$ $\mathrm{ha}^{-1}$ ) was $\sim 23$ for inorganic $\mathrm{N}$ treatments, 68 for TN, 109 for ortho-P, and 37 for TP (TN and TP data from 2007 to 2009 only).

Correlation between ortho-P and TP concentrations per treatment was high $\left(r^{2}=\right.$ 


\section{Figure 4}

Box plots showing distribution of untransformed nutrient load over the study period ([a] nitrate-nitrogen $\left[\mathrm{NO}_{3}-\mathrm{N}\right]$, [b] ammonium- $\mathrm{N}$ [NH $\left.-\mathrm{N}\right]$, [c] total N [TN], [d] ortho-phosphorus [ortho-P], and [e] total P [TP]). Solid lines within boxes represent medians. Samples for TN and TP came from 2007 to 2009 only.

(a)

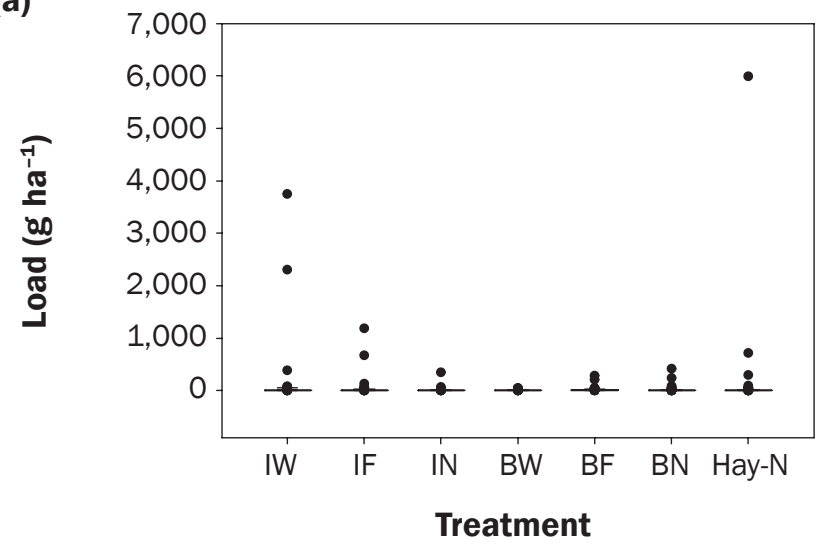

(c)

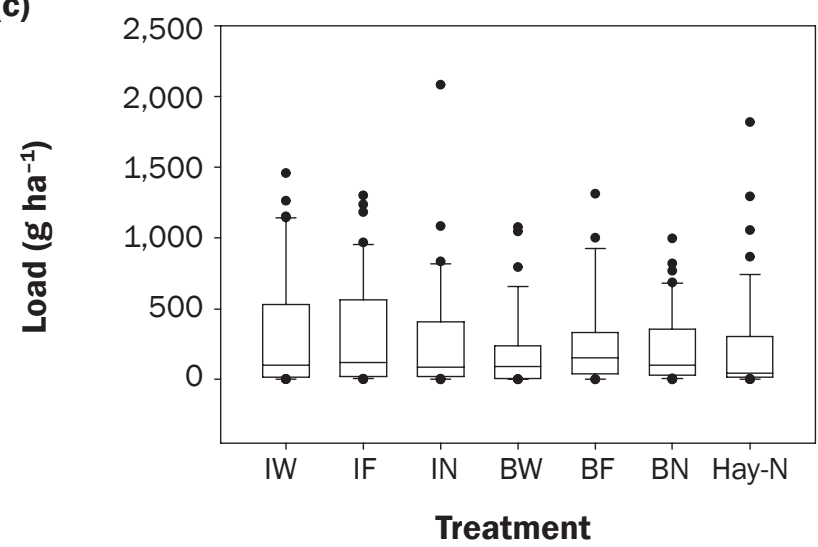

(e)

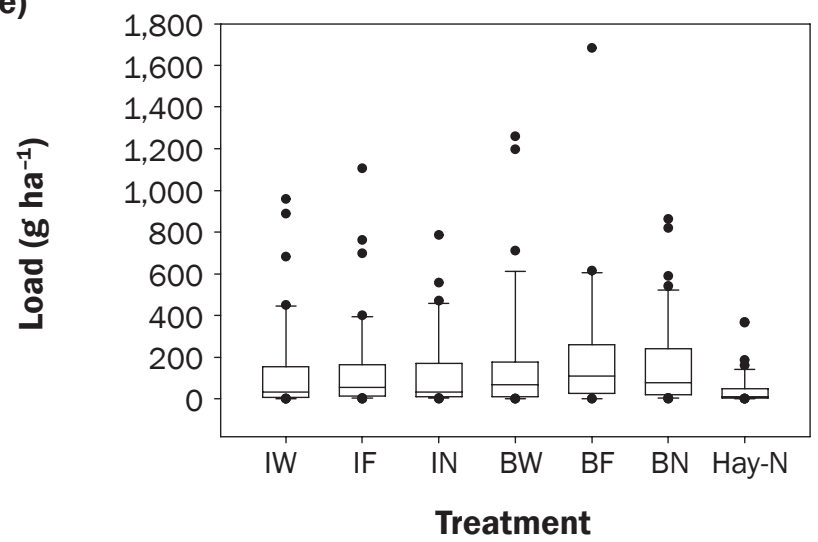

(b)

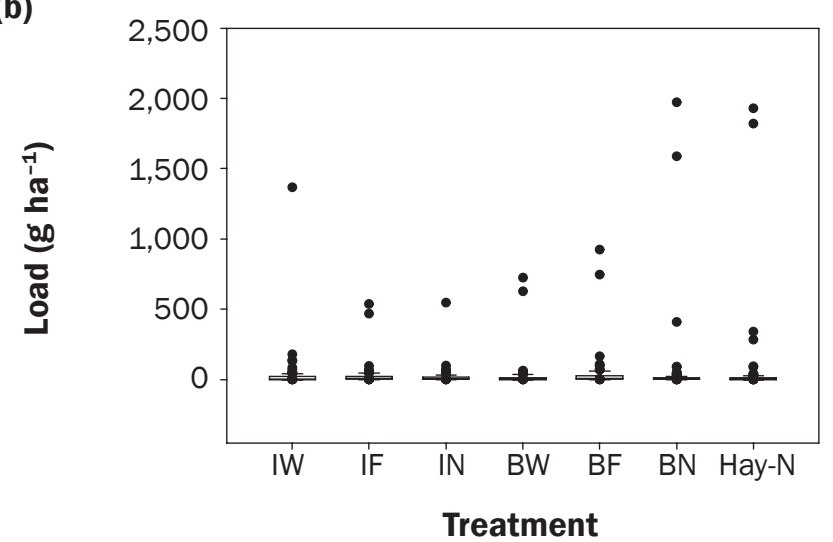

(d)

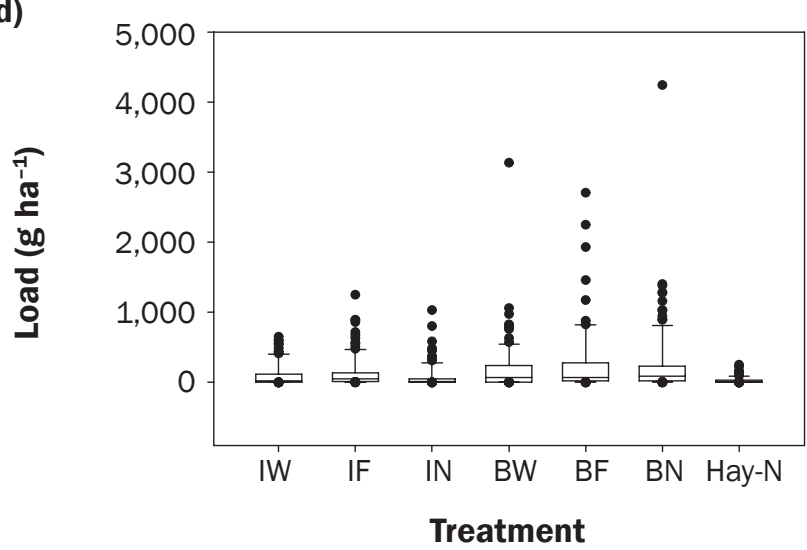

0.89 to 0.98$)$, indicating ortho-P was a major contributor to TP. Ortho-P was $98 \%$ of TP in grazed BL fertilized treatments $(n=116$; $97 \%$ in wild-associated, $99 \%$ in novel- and free-associated fescue), $86 \%$ of TP in grazed inorganic fertilized treatments $(n=113 ; 84 \%$ in wild-associated, $89 \%$ in free-associated, and $83 \%$ in novel-associated fescue), and $76 \%$ of TP in hayed management $(n=49)$.

Similarly, correlation between ortho-P and TP loads was also high $\left(r^{2}=0.87\right.$ to 0.97$)$ with ortho-P load being a major constituent of TP load with some minor variation between treatments. As a percentage of TP load, ortho-P was $84 \%$ of TP in grazed pad- docks with BL fertilization $(n=103 ; 73 \%$ in wild-associated, $83 \%$ in free-associated, and $99 \%$ in novel-associated fescue), $72 \%$ of TP in grazed paddocks with inorganic fertilization $(n=113 ; 74 \%$ in wild-associated, $69 \%$ in free-associated, and $73 \%$ in novel-associated fescue), and $69 \%$ of TP in hayed paddocks $(n=50)$. 


\section{Table 4}

Mixed model analysis of all observations (complete data set) used for evaluating treatment and covariate (as Principal Component [PC]) effects on nutrient concentrations $\left(\mathrm{mg} \mathrm{L}^{-1}\right)$ and loads $\left(\mathrm{g} \mathrm{ha}^{-1}\right)$ in runoff from fescue paddocks at Watkinsville, Georgia. Analysis was conducted on natural log transformed values of concentration and load.

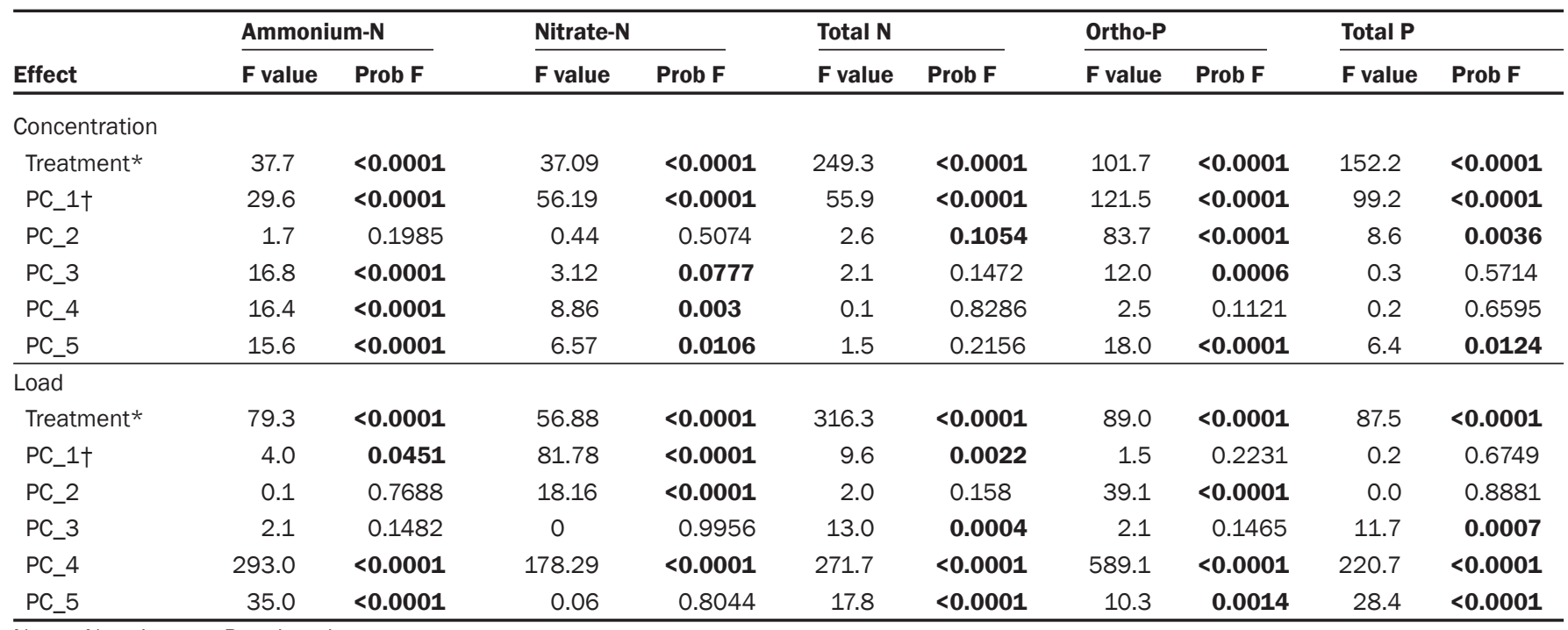

Notes: $\mathrm{N}=$ nitrogen. $\mathrm{P}=$ phosphorus.

*Treatment refers to the six grazing and one haying treatments. Bolded figures indicate statistical significance at $\leq 0.10$.

†Greatest loadings for Principal Components were: PC_1 = DNF, DWOC, DPF, and GCDR; PC_2 = DWC, GAU, and DGZ; PC_3 = APF and ANF; PC_4 = ROV and PAM; and PC_5 = PIN and PDU. Refer to table 3 for acronyms.

Water Quality by Treatment. Results are presented further below per cohort of data (full data set and data in the upper quartile). Here, we briefly discuss the covariates associated with the five PCs (data not shown), which collectively accounted for approximately $11 \%$ of the variance. Dominant loadings of variables were: PC_1 DNF, DWOC, DPF, and GCDR (see table 3 for list of covariate abbreviations); PC_2 DWC, GAU, and DGZ; PC_3 APF and ANF; PC_4 ROV and PAM; and PC_5 PIN and PDU. Dominant variables had loading values greater than 0.80 for the rotated factor pattern except GCDR and DGZ, which had loadings of -0.71 and 0.77 , respectively. Variable loadings for the upper quartile data were essentially the same as those listed above with minor rearrangement of the order.

In the full data set, treatment differences were indicated for concentration and load for all nutrients (table 4). In addition, PC covariates differentially accounted for significant variance for all nutrients. Runoff nutrient concentration and load main effect means for fertilizer source (BL, inorganic) and fescue endophyte status (wild, novel, free) are presented in table 5 along with indications of significant differences. Concentrations of $\mathrm{NH}_{4}-\mathrm{N}$ and $\mathrm{NO}_{3}-\mathrm{N}$ were greater for inorganically fertilized paddocks, while ortho-P and TP concentrations were greater where $\mathrm{BL}$ was the fertilizer source. Concentration of TN was not different due to fertilizer source. Runoff load was greater for TN, ortho-P, and TP for BL fertilized paddocks. This is not surprising since $\mathrm{BL}$ contains about the same amount of both $\mathrm{N}$ and $\mathrm{P}$ but forage grasses typically require three to four times more $\mathrm{N}$ than P (Gaskin et al. 2013). Application of $\mathrm{BL}$ to meet $\mathrm{N}$ requirements of forage grasses leads to accumulation of $\mathrm{P}$ and greater potential for $\mathrm{P}$ release in runoff, which has resulted in the requirement for use of $\mathrm{P}$ based recommendations in the United States to protect water quality (USDA NRCS 2012). Our observation of greater TN loss with BL most likely reflects organic $\mathrm{N}$ loss.

Differences in runoff concentrations of $\mathrm{NH}_{4}-\mathrm{N}, \mathrm{NO}_{3}-\mathrm{N}$, ortho-P, $\mathrm{TN}$, and TP were also observed among fescue endophyte associations (table 5). In general, nutrient concentrations were lower from paddocks with novel-endophyte fescue compared with wild-endophyte fescue. Concentrations tended to be intermediate for the free-endophyte fescue. Results for runoff loads contrasted with those observed for concentration. Loads were greatest for paddocks with free-endophyte fescue compared with the novel-endophyte and wild-endophyte fescues. The result reflects the effects of greater runoff volume from inorganic fertilization compared with BL fertilization as reported by Endale et al. (2013) being expressed to a greater degree in the inorganic $\times$ free fescue compared to remaining fertilizer $\times$ fescue interactions. Changes in soil properties were associated with cattle response to endophyte-fescue association (Franzluebbers et al. 2012b). They reported greater rates of decline of soil bulk density with novel- and wild-endophyte fescue than with endophyte-free fescue $(-0.027$ versus $\left.-0.18 \mathrm{Mg} \mathrm{m}^{-3} \mathrm{y}^{-1}\right)$. Although stocking rates were frequently adjusted to promote similar forage consumption among paddocks, less forage was consumed in the wild-endophyte treatments, resulting in greater residual mass and potentially greater surface residue input during portions of the year (Franzluebbers et al. 2009). Eroded soils in the piedmont are susceptible to crusting due to limited amounts of organic matter at the soil surface (Bruce et al. 1995). Wild-endophyte treatments had greater ground cover at certain times, which would help reduce the negative impacts of precipitation on soil crusting and would promote infiltration (Daniel 2001).

Interaction level treatment means for runoff concentration and load are provided in table 6. Differences in runoff concentration between the grazed and hayed inorganic fer- 
Table 5

Grazed treatment main effect means and $95 \%$ lower and upper confidence limits (LL and UL) from all observations for nutrient concentrations (mg $\mathrm{L}^{-1}$ ) and loads $\left(\mathrm{g} \mathrm{ha}^{-1}\right)$ in runoff from fescue paddocks at Watkinsville, Georgia. Values were back transformed from natural log least square means.

\begin{tabular}{|c|c|c|c|c|c|c|c|c|c|c|c|c|c|c|c|c|c|c|}
\hline \multirow[b]{2}{*}{ Treatment* } & \multicolumn{18}{|c|}{ Nutrient } \\
\hline & AM & LL & UL & & NT & LL & UL & TN & LL & UL & & OP & LL & UL & TP & LL & UL & \\
\hline \multicolumn{19}{|c|}{ Concentration (mg L-1) } \\
\hline $\mathrm{BL}$ & 0.17 & 0.08 & 0.28 & $\mathrm{~B}+$ & 0.14 & 0.07 & $0.22 \mathrm{~B}$ & 2.02 & 1.82 & 3.71 & A & 1.88 & 1.58 & 2.21 & 2.03 & 1.50 & 2.66 & A \\
\hline Inorganic & 0.43 & 0.34 & 0.53 & $A$ & 0.29 & 0.22 & $0.35 \mathrm{~A}$ & 3.15 & 2.33 & 4.18 & A & 1.16 & 0.94 & 1.40 & 1.08 & 0.82 & 1.37 & B \\
\hline Wild & 0.37 & 0.28 & 0.46 & a & 0.24 & 0.18 & $0.30 \mathrm{a}$ & 2.52 & 1.83 & 3.38 & a & 1.55 & 1.30 & 1.84 & 1.69 & 1.47 & 1.93 & a \\
\hline Novel & 0.22 & 0.15 & 0.30 & $\mathrm{~b}$ & 0.16 & 0.11 & $0.22 \mathrm{~b}$ & 2.39 & 1.73 & 3.22 & $\mathrm{~b}$ & 1.33 & 1.09 & 1.59 & 1.35 & 1.13 & 1.59 & b \\
\hline Free & 0.30 & 0.21 & 0.39 & $a b$ & 0.24 & 0.17 & $0.30 \mathrm{a}$ & 3.96 & 2.96 & 5.21 & $a b$ & 1.61 & 1.35 & 1.91 & 1.50 & 1.26 & 1.76 & $a b$ \\
\hline \multicolumn{19}{|l|}{ Load (g ha-1) } \\
\hline $\mathrm{BL}$ & 5.26 & 3.73 & 7.28 & A & 2.65 & 1.82 & $3.71 \mathrm{~A}$ & 197.5 & 112.5 & 345.9 & $\mathrm{~A}$ & 67.35 & 41.51 & 108.90 & A 139.40 & 73.48 & 263.70 & A \\
\hline Inorganic & 6.92 & 5.13 & 9.22 & A & 3.15 & 2.33 & $4.18 \mathrm{~A}$ & 45.4 & 30.6 & 67.2 & $B$ & 24.63 & 14.61 & 41.09 & В 18.68 & 11.14 & 30.90 & B \\
\hline Wild & 5.38 & 3.95 & 7.20 & $\mathrm{~b}$ & 2.52 & 1.83 & $3.38 \mathrm{~b}$ & 74.9 & 57.7 & 97.2 & $\mathrm{~b}$ & 31.54 & 18.69 & 52.76 & 41.22 & 26.42 & 64.01 & $b$ \\
\hline Novel & 5.43 & 3.98 & 7.27 & $\mathrm{~b}$ & 2.39 & 1.73 & $3.22 b$ & 102.8 & 76.9 & 137.3 & a & 38.82 & 23.02 & 65.02 & 54.01 & 34.48 & 84.29 & $a b$ \\
\hline Free & 7.56 & 5.62 & 10.05 & $\mathrm{a}$ & 3.96 & 2.96 & $5.21 \mathrm{a}$ & 112.7 & 84.1 & 151.0 & a & 56.24 & 33.98 & 92.67 & 62.28 & 39.83 & 97.06 & a \\
\hline
\end{tabular}

\section{Table 6}

Interaction level treatment means and 95\% lower and upper confidence limits (LL and UL) for all observations for nutrient concentrations (mg $\mathrm{L}^{-1}$ ) and loads $\left(\mathrm{g} \mathrm{ha}^{-1}\right)$ in runoff from fescue paddocks at Watkinsville, Georgia. Values were back transformed from natural log least square means.

\begin{tabular}{|c|c|c|c|c|c|c|c|c|c|c|c|c|c|c|c|c|c|c|c|}
\hline \multirow[b]{2}{*}{ Treatment* } & \multicolumn{19}{|c|}{ Nutrient } \\
\hline & AM & LL & UL & NT & LL & UL & & TN & LL & UL & & OP & LL & UL & & TP & LL & UL & \\
\hline \multicolumn{20}{|c|}{ Concentration (mg L-1) } \\
\hline WLG & 0.27 & 0.14 & 0.42 & 0.17 & 0.08 & 0.26 & & 2.52 & 1.84 & 3.35 & & 2.26 & 1.89 & 2.67 & & 2.60 & 1.96 & 3.37 & \\
\hline$N L G$ & 0.07 & -0.04 & 0.19 & 0.10 & 0.01 & 0.19 & & 1.66 & 1.09 & 2.38 & & 1.70 & 1.39 & 2.05 & & 1.68 & 1.15 & 2.34 & \\
\hline FLG & 0.19 & 0.05 & 0.36 & 0.17 & 0.06 & 0.29 & & 1.95 & 1.28 & 2.81 & & 1.74 & 1.39 & 2.14 & & 1.89 & 1.27 & 2.67 & \\
\hline WFG & 0.48 & 0.34 & 0.63 & 0.32 & 0.23 & 0.43 & & 3.12 & 2.44 & 3.92 & & 1.00 & 0.78 & 1.25 & & 1.01 & 0.71 & 1.37 & \\
\hline NFG† & 0.40 & 0.27 & $0.55 \mathbf{a}$ & 0.23 & 0.15 & 0.33 & $\mathbf{a}$ & 2.80 & 2.14 & 3.60 & $\mathbf{a}$ & 1.01 & 0.79 & 1.26 & a & 1.06 & 0.73 & 1.45 & $\mathbf{a}$ \\
\hline FFG & 0.42 & 0.29 & 0.56 & 0.31 & 0.22 & 0.40 & & 2.98 & 2.35 & 3.72 & & 1.50 & 1.23 & 1.79 & & 1.17 & 0.85 & 1.54 & \\
\hline NFH & 0.35 & 0.23 & $0.48 \mathbf{a}$ & 0.25 & 0.17 & 0.34 & $\mathbf{a}$ & 2.45 & 1.92 & 3.08 & a & 0.47 & 0.32 & 0.65 & b & 0.40 & 0.21 & 0.63 & b \\
\hline \multicolumn{20}{|l|}{ Load (g ha-1) } \\
\hline WLG & 4.77 & 3.20 & 6.92 & 2.15 & 1.34 & 3.23 & & 148.3 & 83.2 & 263.7 & & 55.8 & 34.0 & 91.0 & & 110.2 & 57.8 & 209.5 & \\
\hline NLG & 4.65 & 3.09 & 6.81 & 2.38 & 1.50 & 3.58 & & 250.2 & 130.6 & 478.5 & & 76.5 & 46.7 & 125.0 & & 170.9 & 83.2 & 349.8 & \\
\hline FLG & 6.56 & 4.23 & 9.93 & 3.57 & 2.22 & 5.51 & & 210.7 & 104.9 & 422.3 & & 72.4 & 43.0 & 121.7 & & 146.0 & 68.0 & 312.0 & \\
\hline WFG & 6.05 & 4.20 & 8.56 & 2.94 & 1.97 & 4.22 & & 37.6 & 22.9 & 61.5 & & 17.7 & 10.6 & 29.1 & & 15.0 & 8.2 & 26.9 & \\
\hline NFG & 6.31 & 4.41 & 8.89 a & 2.40 & 1.57 & 3.50 & $\mathbf{a}$ & 41.9 & 24.7 & 70.5 & a & 19.4 & 11.7 & 31.9 & a & 16.6 & 8.9 & 30.3 & $\mathbf{a}$ \\
\hline FFG & 8.69 & 6.24 & 11.98 & 4.37 & 3.11 & 6.02 & & 60.1 & 37.5 & 95.9 & & 43.6 & 26.7 & 70.7 & & 26.2 & 14.9 & 45.6 & \\
\hline NFH & 4.62 & 3.22 & $6.50 \mathbf{b}$ & 2.85 & 1.96 & 4.00 & $\mathbf{a}$ & 34.2 & 21.5 & 54.0 & $\mathbf{a}$ & 7.5 & 4.3 & 12.6 & b & 6.7 & 3.5 & 12.0 & b \\
\hline
\end{tabular}

*Three letter treatment designations represent fescue, fertilizer, and forage management, respectively. Fescue = wild $(W)$, novel $(N)$, and free $(F)$. Fertilizer $=$ broiler litter $(L)$ and inorganic fertilizer $(F)$. Forage management $=$ grazed $(G)$ and hayed $(H)$.

†Bolded cells are for the comparison of grazed versus hayed paddocks under novel-endophyte fescue with inorganic fertilization. Differences indicated at $p<0.10$.

tilized novel-endophyte fescue treatments were observed for ortho-P and TP concentrations and load, and for $\mathrm{NH}_{4}-\mathrm{N}$ load. Removal of nutrients in baled hay and lack of animal manure on the soil surface most likely contributed to reduced P losses from the hayed paddocks.
Results from the mixed models analysis of the upper quartile of data are presented in table 7. As for the full data set, treatment effects were detected for runoff concentra- 


\section{Table 7}

Mixed model analysis on upper quartile cohort of observations evaluating treatment and covariate (as Principal Component [PC]) effects on nutrient concentrations ( $\mathrm{m} \mathrm{L} \mathrm{L}^{-1}$ ) and loads $\left(\mathrm{g} \mathrm{ha}^{-1}\right)$ in runoff from fescue paddocks at Watkinsville, Georgia. Analysis was conducted on natural log transformed values of concentration and load.

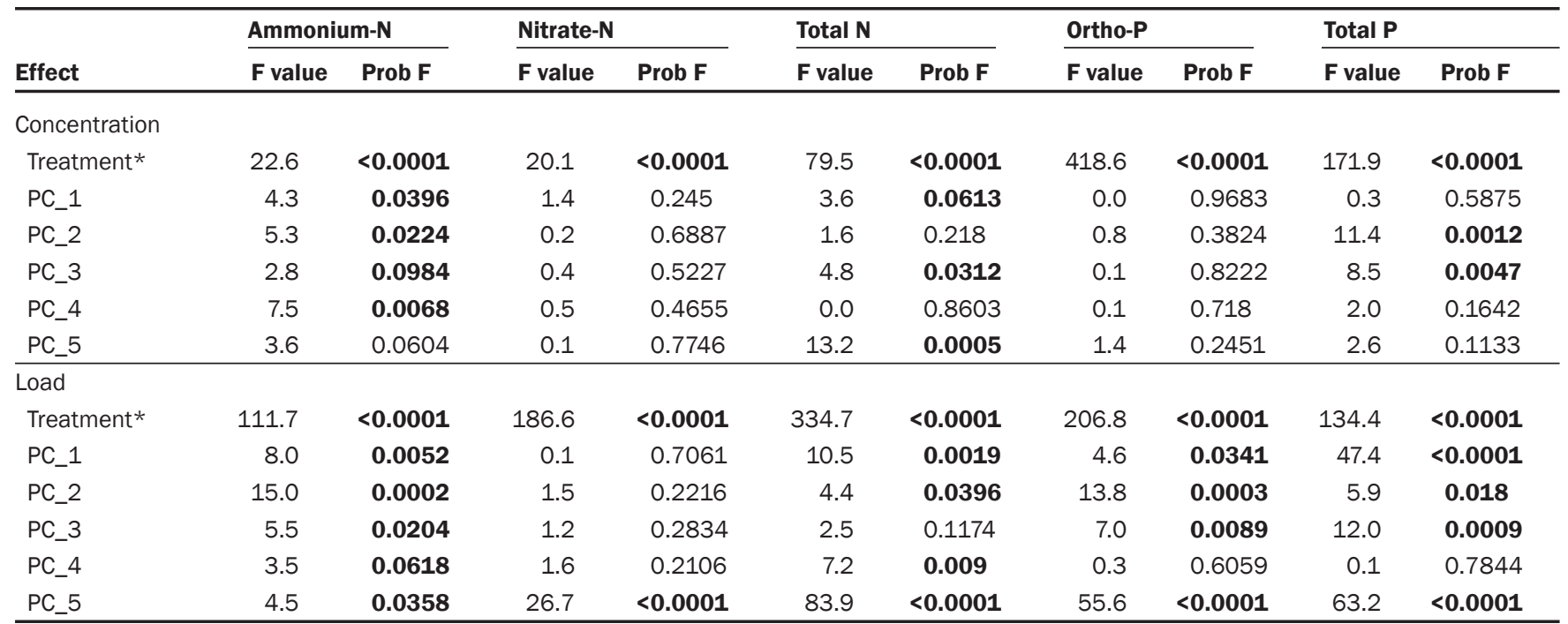

Notes: $\mathrm{N}=$ nitrogen. $\mathrm{P}=$ phosphorus.

*Treatment refers to the six grazing and one haying treatments. Bolded figures indicate statistical significance at $\leq 0.10$. Greatest loadings for Principal Components were: PC_1 = DNF, DWOC, DPF, and GCDR; PC_2 = DZG, DWC, and GAU; PC_3 = PDU and PIN; PC_4 = APF and ANF; and PC_5 = ROV, PAM, and DSLR. Note slight difference with those in table 3. Refer to table 3 for acronyms.

\section{Table 8}

Grazed treatment main effect means and $95 \%$ lower and upper confidence limits (LL and UL) for upper quartile cohort of observations nutrient concentrations ( $\mathrm{mg} \mathrm{L}^{-1}$ ) and loads $\left(\mathrm{g} \mathrm{ha}^{-1}\right)$ in runoff from fescue paddocks at Watkinsville, Georgia. Values were back transformed from natural log least square means.

\begin{tabular}{|c|c|c|c|c|c|c|c|c|c|c|c|c|c|c|c|c|c|c|c|c|}
\hline \multirow[b]{2}{*}{ Treatment* } & \multicolumn{20}{|c|}{ Nutrient } \\
\hline & AM & LL & UL & & NT & LL & UL & & TN & LL & UL & & OP & LL & UL & & TP & LL & UL & \\
\hline \multicolumn{21}{|c|}{ Concentration (mg L-1) } \\
\hline $\mathrm{BL}$ & 0.86 & 0.47 & 1.35 & A† & 0.62 & 0.34 & 0.96 & $A$ & 5.27 & 3.49 & 7.75 & A & 5.01 & 4.30 & 5.80 & $A$ & 3.92 & 2.93 & 5.16 & A \\
\hline Inorganic & 1.44 & 1.04 & 1.93 & A & 1.07 & 0.79 & 1.39 & A & 4.81 & 3.57 & 6.38 & A & 2.47 & 2.16 & 2.81 & $A$ & 2.96 & 2.39 & 3.63 & A \\
\hline Wild & 1.49 & 1.10 & 1.96 & a & 0.95 & 0.69 & 1.25 & a & 6.10 & 4.78 & 7.70 & $a$ & 3.54 & 3.20 & 3.91 & $\mathrm{~b}$ & 3.90 & 3.37 & 4.51 & a \\
\hline Novel & 0.83 & 0.55 & 1.17 & $b$ & 0.63 & 0.42 & 0.86 & $b$ & 4.45 & 3.41 & 5.74 & $b$ & 3.15 & 2.84 & 3.50 & c & 2.98 & 2.50 & 3.53 & $b$ \\
\hline Free & 1.13 & 0.77 & 1.56 & $a b$ & 0.93 & 0.66 & 1.25 & a & 4.71 & 3.62 & 6.06 & $\mathrm{~b}$ & 4.07 & 3.66 & 4.51 & $\mathrm{a}$ & 3.43 & 2.90 & 4.02 & $a b$ \\
\hline \multicolumn{21}{|l|}{ Load (g ha-1) } \\
\hline $\mathrm{BL}$ & 27.1 & 16.3 & 44.5 & $\mathrm{~B} \dagger$ & 24.9 & 15.9 & 38.7 & A 1 & 1,259 & 720 & 2,202 & A & 589 & 376 & 923 & A & 470 & 192 & 1,145 & A \\
\hline Inorganic & 53.2 & 35.0 & 80.6 & A & 24.1 & 17.2 & 33.5 & A & 448 & 316 & 636 & B & 245 & 152 & 394 & B & 284 & 154 & 522 & A \\
\hline Wild & 40.4 & 27.0 & 60.3 & a & 22.8 & 16.4 & 31.5 & $a b$ & 690 & 592 & 804 & $\mathrm{~b}$ & 329 & 202 & 536 & $\mathrm{~b}$ & 376 & 228 & 618 & $a b$ \\
\hline Novel & 28.7 & 19.1 & 42.9 & $b$ & 19.6 & 14.2 & 26.8 & $b$ & 731 & 607 & 882 & $a b$ & 337 & 205 & 554 & $b$ & 316 & 194 & 515 & $b$ \\
\hline Free & 47.8 & 31.6 & 71.9 & a & 33.2 & 23.7 & 46.4 & a & 857 & 706 & 1,041 & $\mathrm{a}$ & 503 & 312 & 811 & a & 417 & 256 & 678 & a \\
\hline
\end{tabular}

tion and load of $\mathrm{NH}_{4}-\mathrm{N}, \mathrm{NO}_{3}-\mathrm{N}$, ortho-P, TP, and TN. Results of contrasts evaluating differences in nutrient concentrations and loads due to fertilizer source or fescue endophyte association for the upper quartile cohort are presented in table 8 .

Runoff nutrient concentration response within the upper quartile data were similar for the two fertilizer sources (table 8).
However, fertilizer source influences on loads were evident for $\mathrm{NH}_{4}-\mathrm{N}$ (inorganic $>$ $\mathrm{BL}$ ) and for TN and ortho-P (BL > inorganic). The effect of the fescue endophyte 
Table 9

Treatment level means and $95 \%$ lower and upper confidence limits (LL and UL) for upper quartile cohort of observations for nutrient concentrations ( $\mathrm{mg} \mathrm{L}^{-1}$ ) and loads $\left(\mathrm{g} \mathrm{ha}^{-1}\right.$ ) in runoff from fescue paddocks at Watkinsville, Georgia. Values were back transformed from log least square means.

\begin{tabular}{|c|c|c|c|c|c|c|c|c|c|c|c|c|c|c|c|c|c|c|c|c|}
\hline \multirow[b]{2}{*}{ Treatment* } & \multicolumn{20}{|c|}{ Nutrient } \\
\hline & AM & LL & UL & & NT & LL & UL & & TN & LL & UL & & OP & LL & UL & & TP & LL & UL & \\
\hline \multicolumn{21}{|c|}{ Concentration (mg L ${ }^{-1}$ ) } \\
\hline WLG & 1.29 & 0.72 & 2.06 & & 0.69 & 0.34 & 1.14 & & 7.25 & 4.93 & 10.47 & & 5.64 & 4.79 & 6.60 & & 5.30 & 3.95 & 7.03 & \\
\hline NLG & 0.46 & 0.09 & 0.95 & & 0.45 & 0.14 & 0.84 & & 4.14 & 2.52 & 6.50 & & 4.36 & 3.62 & 5.21 & & 3.09 & 2.10 & 4.41 & \\
\hline FLG & 0.94 & 0.36 & 1.77 & & 0.73 & 0.30 & 1.30 & & 4.85 & 2.86 & 7.86 & & 5.13 & 4.20 & 6.23 & & 3.64 & 2.51 & 5.12 & \\
\hline WFG & 1.72 & 1.07 & 2.57 & & 1.25 & 0.80 & 1.80 & & 5.10 & 3.61 & 7.08 & & 2.11 & 1.75 & 2.51 & & 2.82 & 2.10 & 3.69 & \\
\hline NFG† & 1.31 & 0.77 & 2.02 & $\mathbf{a}$ & 0.82 & 0.47 & 1.26 & a & 4.79 & 3.33 & 6.75 & $\mathbf{a}$ & 2.22 & 1.85 & 2.64 & a & 2.88 & 2.14 & 3.80 & a \\
\hline $\mathrm{FFG}$ & 1.33 & 0.82 & 2.00 & & 1.16 & 0.76 & 1.66 & & 4.57 & 3.23 & 6.33 & & 3.18 & 2.73 & 3.70 & & 3.22 & 2.50 & 4.10 & \\
\hline NFH & 1.19 & 0.71 & 1.81 & $\mathbf{a}$ & 0.94 & 0.58 & 1.37 & $\mathbf{a}$ & 4.62 & 3.25 & 6.43 & $\mathbf{a}$ & 0.97 & 0.76 & 1.21 & b & 1.28 & 0.88 & 1.76 & b \\
\hline \multicolumn{21}{|l|}{ Load (g ha ${ }^{-1}$ ) } \\
\hline WLG & 24.5 & 14.0 & 42.6 & & 16.6 & 9.5 & 28.5 & & 1,114 & 673 & 1,842 & & 494 & 314 & 777 & & 516 & 232 & 1,147 & \\
\hline$N L G$ & 20.8 & 11.6 & 36.6 & & 23.1 & 13.2 & 40.1 & & 1,312 & 711 & 2,422 & & 594 & 379 & 931 & & 404 & 153 & 1,065 & \\
\hline FLG & 39.1 & 19.9 & 75.9 & & 40.5 & 20.6 & 78.5 & & 1,395 & 736 & 2,643 & & 711 & 443 & 1,141 & & 505 & 185 & 1,374 & \\
\hline WFG & 66.1 & 39.2 & 111.1 & & 31.2 & 18.8 & 51.3 & & 427 & 293 & 623 & & 219 & 140 & 344 & & 273 & 145 & 516 & \\
\hline NFG & 39.4 & 23.5 & 65.6 & $\mathbf{a}$ & 16.5 & 10.0 & 26.9 & $\mathbf{a}$ & 407 & 273 & 608 & a & 192 & 122 & 300 & a & 247 & 127 & 481 & a \\
\hline $\mathrm{FFG}$ & 58.4 & 35.9 & 94.6 & & 27.2 & 17.1 & 43.0 & & 527 & 361 & 768 & & 356 & 227 & 559 & & 344 & 182 & 650 & \\
\hline NFH & 37.5 & 23.0 & 60.7 & $\mathbf{a}$ & 23.3 & 14.6 & 36.7 & $\mathbf{a}$ & 378 & 258 & 555 & $\mathbf{a}$ & 74 & 47 & 117 & b & 116 & 61 & 218 & b \\
\hline
\end{tabular}

*Three letter treatment designations represent fescue, fertilizer, and forage management, respectively: Fescue $=$ wild $(W)$, novel $(N)$, and free $(F)$. Fertilizer $=$ broiler litter $(L)$ and inorganic fertilizer $(F)$. Forage management $=$ grazed $(G)$ and hayed $(H)$.

†Bolded cells are for the comparison of grazed versus hayed paddocks under novel-endophyte fescue with inorganic fertilization. Differences indicated at $p<0.10$.

association varied with nutrient, and no clear indication of trend is apparent.

Interaction level treatment means for runoff concentration and load for the upper quartile of data are provided in table 9. Differences in runoff concentration between the grazed and hayed inorganic fertilized novel-endophyte fescue treatments were observed for ortho-P and TP concentrations and load. Removal of nutrients in baled hay and lack of animal manure on the soil surface most likely contributed to reduced $\mathrm{P}$ losses from the hayed paddocks. Losses of $\mathrm{NH}_{4}$ and $\mathrm{NO}_{3}^{-}$although not desirable were relatively low (over the study period, $\sim 2.8 \mathrm{~kg} \mathrm{ha}^{-1} \mathrm{y}^{-1}$ for both for all observations; supplemental table S5).

The results above reflect the complexities of interactions of the various factors that determine temporal and spatial nutrient loss patterns from pastures. Five PCs encompassing several cattle, hydrologic, and management variables were needed as covariates to isolate treatment effects. Endale et al. (2013) showed how one of the variables, runoff, encompassed in PC_4, is itself affected by other factors. Through PC analysis using 23 variables, Endale et al. (2013) identified event rainfall amount, flow path order \#1, cumulative percentage area up to slope class 2, and area-weighted slope as critical variables to account for effects of landscape on runoff variability at this site.

Endale et al. (2017) presented a summary of results on ortho-P and TP concentrations and loads from four other studies alongside results from their 1999 to 2009 study at a 7.7 ha rotationally grazed pasture $1.5 \mathrm{~km}$ northeast of the present study. Results were similar from all five studies. For example, concentration of ortho-P ( $\mathrm{mg} \mathrm{L}^{-1}$ ) ranged 0.6 to 24.2 in manure applied fields and 0.6 to 3.8 in inorganically fertilized fields (Edwards et al. 1996); 4.6 to 14.2 (Nash et al. 2000); and 0.3 to 7.5 (Endale et al. 2017), which are similar to ranges observed in the current study.

Endale et al. (2017) showed that a few large storms accounted for most of the total $\mathrm{P}$ loss. Further, runoff events occurring within 24 hours of fertilization resulted in greatest runoff concentrations, as would be expected. Over the 10 years of data, the six largest P load events (probability of exceedance $<15 \%$ ) accounted for $53 \%$ of the total $\mathrm{P}$ loss from all 43 monitored events and coincided with cattle presence in the watershed. As shown in the current study (above), total nutrient loads from data in the upper quartile were several fold greater compared with the rest of the data.

Loss of TP in the current study was estimated as being $4.0 \%$ of the total $\mathrm{P}$ applied from inorganic, BL, and manure sources. Total $\mathrm{P}$ lost in runoff was estimated as $147 \mathrm{~kg} \mathrm{ha}^{-1}$ with an assumption of ortho-P being $75 \%$ of total P (had ortho-P data for whole period whereas TP data came from 2007 through 2009). Total P applied from inorganic (18-9$18)$ and organic (BL) sources was estimated at $466 \mathrm{k} \mathrm{ha}^{-1}$ assuming $1.0 \mathrm{~kg} \mathrm{P}$ per $80.0 \mathrm{~kg}$ $\mathrm{BL}$ (unpublished data). Estimated P in cattle manure during the 15 grazing periods was $3,227 \mathrm{~kg} \mathrm{ha}^{-1}$.

\section{Summary and Conclusions}

Runoff nutrient concentrations and loads of $\mathrm{N}$ and $\mathrm{P}$ species from tall fescue pastures in the Southern Piedmont were evaluated over eight years for three management variables: (1) tall fescue-endophyte association (wild, novel, and free); (2) nutrient source (BL and inorganic fertilizer); and (3) harvest management (grazing and haying). The following points identify significant results and conclusions:

- Tall fescue with novel-endophyte association had lower or equal runoff concentrations and loads for inorganic 
$\mathrm{N}$, ortho-P, and TP compared to wild- or free-endophyte fescue associations. Based on our results and previous companion results, novel-endophyte fescue (1) poses no additional risk of runoff compared to other endophyte fescue paddocks, and (2) has improved average daily gain by cattle and stand persistence, therefore its adoption in the southeastern United States, regardless of fertilization source, is encouraged.

- Weather variability plays a significant role in nutrient losses from grazed systems in the region. Mean total runoff from all paddocks were 15.2- and 1.9-fold greater during above average (27.2\%) and average $(20.6 \%)$ compared to below average (52.2\%) monthly rainfall periods. Across all paddocks, nutrient loads were 3.4-fold (TP) to 14.6-fold $\left(\mathrm{NH}_{4}-\mathrm{N}\right)$ greater from above average compared to below average monthly rainfall periods. Modelers, land managers, and policy makers can use these data to better assess impacts of variable weather, field-scale pasture attributes, and management on water quantity and quality.

- Use of PC that encompass temporal and spatial factors in our analysis of variance allowed us to isolate true treatment effects on nutrient loss patterns from pastures. A similar approach was used in a previous companion report on runoff variability. Covariance analysis with the PCs proved to be a valuable tool. These analyses reflect on the complexities of interactions of the various factors that determine temporal and spatial nutrient loss patterns from pastures.

- Most nutrient losses occur from few elevated levels of pollutant fluxes the result of the convergence of hydrologic events favoring pollutant transport along with forage and fertilizer management variables. Pollutant loads in the upper quartile were several fold greater than those from the rest of the data. The presence of cattle increased ortho-P load up to three-fold compared with periods with no cattle, for example.

- Maintaining forage at a threshold to avoid overgrazing is a management strategy for improved nutrient cycling as evidenced by loss of only $4 \%$ of the applied inorganic $\mathrm{P}$ and from cattle manure.

\section{Supplemental Material}

Supplemental material for this manuscript is provided that adds and describes five additional data tables and one fig- ure. https://www.ars.usda.gov/southeast-area/tifton-ga/ southeast-watershed-research/research/documentation/ supplementary-information/.

\section{Acknowledgements}

This research is a contribution of the USDA Agricultural Research Service (ARS) Gulf Atlantic Coastal Plain LongTerm Agroecosystem Research site. The paper is dedicated to the memory of our colleague John Stuedemann (1942 to 2017) who was the driving force behind fescue toxicosis research in the southeast for more than 36 years, most of which was conducted at the USDA ARS Research Center in Watkinsville, Georgia. John was an animal scientist and authority on fescue toxicosis and control and treatment of internal parasites in cattle. John played a crucial role in establishing this study, spearheading the animal component. His infectious smile and midwestern dry humor are missed by all who worked with him. The following personnel provided a critical mass of competent technical support for which we are most grateful. Hydrologic and analytic aspect: Stephen Norris and Robert Martin; paddock layout and construction as self-contained catchments: Anthony Dillard, Robert Sheats, Fred Hale, Ronald Phillips, and Deborah Beese; grazing and haying management including data gathering and compilation: Steve Knapp, Eric Elsner, the Land Herd Management crew headed by Clara Parker, farm manager; and miscellaneous support from students and many additional technical staff. The research was supported in part by USDA ARS base funding, the Office of Science (BER), US Department of Energy, Grant No. DE-IA02-00ER63021, and USDA National Research Initiative, Soil Processes Program, Grant No. 2007-35107-17868. Support was also received during data compilation, processing, and manuscript preparation from USDA National Resource Conservation Service through US Government Interagency Agreement \#67-3A75-17-472 "CEAP-Grazing Lands APEX modeling on Pasturelands."

\section{Disclaimer}

The use of trade, firm, or corporation names in this publication is for the information and convenience of the reader. Such use does not constitute an official endorsement or approval by the United States Department of Agriculture, the Agricultural Research Service, or the University of Georgia, of any product or service to the exclusion of others that may be suitable.

\section{References}

Bacon, C.W., and M.R. Siegel. 1988. Endophyte parasitism of tall fescue. Journal of Production Agriculture 1:45-55.

Belesky, D.P., and C.P. West. 2009. Abiotic stresses and endophyte effects. In Tall Fescue for the Twenty-First Century, eds. H.A. Fribourg, D.B. Hannaway, and C.P. West, Agronomy Monographs 53, 49-64. Madison, WI: American Society of Agronomy, Crop Science Society of America, and Soil Science Society of America.

Bos,M.G.1978.Discharge measurement structures.Publication 20. Wageningen, The Netherlands: International Institute for Land Reclamation and Improvement.
Bouton, J.H., G.C.M. Latch, N.S. Hill, C.S. Hoveland, M.A. McCann, R.H. Watson, J.A. Parrish, L.L. Hawkins, and F.N.Thompson. 2002. Reinfection of tall fescue cultivars with non-ergot alkaloid-producing endophytes. Agronomy Journal 94:567-574.

Brakensiek, D.L., H.B. Osborn, and W.J. Rawls. 1979. Filed manual for research in agricultural hydrology. Agricultural Handbook 224. Washington, DC: USDA.

Crooke, W.M., and W.E. Simpson. 1971. Determination of ammonium on Kjeldahl digests of crops by an automated procedure. The Journal of the Science of Food and Agriculture 22:9-10.

Daniel, J.A. 2001. Erosion Studies from Experimental Watersheds Impacted by Livestock Grazing. In Soil Erosion. St. Joseph, MI:American Society of Agricultural and Biological Engineers.

Edwards, D.R., T.C. Daniel, J.F. Murdoch, and P.A. Moore Jr. 1996. Quality of runoff from four northwest Arkansas pasture fields treated with organic and inorganic fertilizer. Transactions of the ASAE 39(5):1689-1696.

Endale, D.M., D.S. Fisher, L.B. Owens, M.B. Jenkins, H.H. Schomberg, C.L. Tebes-Stevents, and J.V. Bonta. 2011. Runoff water quality during drought in a Zero-Order Georgia Piedmont pasture: Nitrogen and total organic carbon. Journal of Environmental Quality 40:969-979.

Endale, D.M., A.J. Franzluebbers, J.A. Stuedemann, D.S. Seman, D.H. Franklin, and H.H. Schomberg. 2013. Runoff under natural rainfall from small tall fescue catchments in the Georgia Piedmont, United States. Journal of Soil and Water Conservation 68(6):474-486, https://doi.org/10.2489/jswc.68.6.474.

Franson, M.A.H. 1998a. 4500-P phosphorus. In Standard Methods for the Examination of Water and Wastewater, 20th edition, 4-139-4-144. Washington, DC: American Public Health Association.

Franson, M.A.H. 1998b. 4500-Norg D block digestion and flow injection analysis. In Standard Methods for the Examination of Water and Wastewater, 20th edition, 4-126-4-128. Washington, DC: American Public Health Association.

Franzluebbers, A.J. 2007. Integrated crop-livestock systems in the southeastern USA. Agronomy Journal 99:361-372.

Franzluebbers, A.J., D.M. Endale, J.S. Buyer, and J.A. Stuedemann. 2012a. Tall fescue management in the Piedmont: Sequestration of soil organic carbon and total nitrogen. Soil Science of American Journal 76:101601026.

Franzluebbers, A.J., L.K. Paine, J.R. Winsten, M. Krome, M.A. Sanderson, K. Ogles, and D. Thompson. 2012b. Well-managed grazing systems: A forgotten hero of conservation. Journal of Soil and Water Conservation 67(4):100A-104A, https://doi.org/10.2489/ jswc.67.4.100A.

Franzluebbers, A.J., D.H. Seman, and J.A. Stuedemann. 2009. Tall fescue persists and cattle perform well on a novelendophyte association in the Southern Piedmont. Forest and Grazinglands doi:10.1094/FG-2009-0227-01-RS. 
Franzluebbers, A.J., and J.A. Stuedemann. 2006. Pasture and cattle responses to fertilization and endophyte association in the southern Piedmont, USA. Agriculture Ecosystems \& Environment 114:217-225.

Fribourg, H.A., D.B. Hannaway, and C.P. West. 2009. Chapter 29: Accomplishments and Challenges. In Tall Fescue for the Twenty-First Century, eds. H.A. Fribourg, D.B. Hannaway, and C.P. West, 511-515. Agronomy Monographs 53. Madison, WI: American Society of Agronomy, Crop Science Society of America, and Soil Science Society of America.

Gaskin, J., G. Harris, A. Franzluebbers, and J. Andrae. 2013. Poultry Litter Applications on Pastures \& Hayfields. Bulletin 1330. Athens, GA: University of Georgia, College of Agricultural and Environmental Sciences Cooperative Extension.

Gunter, S.A., and P.A. Beck. 2004. Novel endophyte-infected tall fescue for growing beef cattle. Journal of Animal Science 82:E75-E82.

Hannaway, D.B., C. Daly, M. Halbleib, D. James, C.P. West, J.J.Volenec, D. Chapman, X. Li, W. Cao, J. Shen, X. Shi, and S. Johnson. 2009. Development of suitability maps with examples for the United States and China. In Tall Fescue for the Twenty-First Century, eds. H.A. Fribourg, D.B. Hannaway, and C.P. West, 33-48. Agronomy Monographs 53. Madison, WI: American Society of Agronomy, Crop Science Society of America, and Soil Science Society of America.

Hill, N.S., F.N. Thompson, D.L. Dawe, and J.A. Stuedemann. 1994. Antibody binding of circulating ergot alkaloids in cattle grazing tall fescue. American Journal of Veterinary Research 55:419-424.

Hopkins, A.A., M.C. Saha, and Z.Y. Wang. 2009. Breeding, genetics, and cultivars. In Tall Fescue for the Twenty-First Century, eds. H.A. Fribourg, D.B. Hannaway, and C.P. West, 339-366. Agronomy Monographs 53. Madison, WI: American Society of Agronomy, Crop Science Society of America, and Soil Science Society of America.

Hoveland, C.S. 2009. Origin and history. In Tall Fescue for the Twenty-First Century, eds. H.A. Fribourg, D.B. Hannaway, and C.P.West, 3-11. Agronomy Monographs 53. Madison, WI:American Society of Agronomy, Crop Science Society of America, and Soil Science Society of America.

Keeney, D.R., and D.W. Nelson. 1982. Nitrogen-Inorganic forms. In Methods of Soil Analysis. Part 2, 2nd edition, ed. A.L. Page et al., 643-649. Agronomy Monograph No. 9. Madison, WI:American Society of Agronomy and Soil Science Society of America.

Kellogg, R.L., D.C. Moffitt, and N. Gollehon. 2014. Estimates of recoverable and non-recoverable manure nutrients based on the census of agriculture. Washington, DC: USDA Natural Resources Conservation Service, Resource Assessment Division, Resource Economics and Analysis Division.

Leuchtmann, A., C.W. Bacon, C.L. Schardl, J.F. White, and M. Tadych. 2014. Nomenclatural realignment of
Neotyphodium species with genus Epichloë. Mycologia 106(2):202-215, doi:10.3852/13-251.

Murphy, J., and J.P. Riley. 1962. A modified single solution method for determination of phosphate in natural waters. Analytica Chimica Acta 27:31-36.

Nash, D.M., M. Hannah, D. Halliwell, and C. Murdoch. 2000. Factors affecting phosphorus export from a pasturebased grazing system. Journal of Environmental Quality 29(4):1160-1166.

Omacini, M., M. Semmartin, L.I. Pérez, and P.E. Gundel. 2012. Grass endophyte symbiosis: A neglected aboveground interaction with multiple belowground consequences. Applied Soil Ecology 61:273-279.

Phillip, D., M.P. Popp, E.R. Rumley, M.C. Savin, and K.P. Coffey. 2015. Regulatory, production, and consumerbased challenges of forage-based cattle production systems in the southeastern United States. Animal Frontiers 5(4):24-31.

Ritz, C.W., and W.C. Merka. 2013. Maximizing poultry manure use through nutrient management planning. Bulletin 1245. Athens, GA: University of Georgia, College of Agricultural and Environmental Sciences Cooperative Extension.

Roberts, C.A., G.D. Lacefield, D. Ball, and G. 2009. Bates. Management to optimize grazing performance in the Northern Hemisphere. In Tall Fescue for the TwentyFirst Century, eds. H.A. Fribourg, D.B. Hannaway, and C.P. West, 85-99. Agronomy Monographs 53. Madison, WI: American Society of Agronomy, Crop Science Society of America, and Soil Science Society of America.

Rogers, J.K., and J.M. Locke. 2013. Tall fescue. History, application, establishment and management. Pub No. NF-FO-13.03. Ardmore, OK: The Samuel Roberts Noble Foundation.

SAS Inst. 2014. SAS Enterprise Guide ver. 7.1. Cary, NC: SAS Institute.

Shelby, R.A., and L.W. Darlymple. 1987. Incidence and distribution of the tall fescue endophyte in the United States. Plant Disease 71:783-786.

Starkey, J. 2003. Georgia's response to the new federal CAFO rule. Guest editorial. Poultry Tech 15(2).

Stuedemann, J.A., and C.S. Hoveland. 1988. Fescue endophyte: History and impact on animal agriculture. Journal of Production Agriculture 1:39-44.

USDA NRCS (Natural Resources Conservation Service). 2001. Plant guide. Tall fescue. Washington, DC: USDA Natural Resources Conservation Service.

USDA NRCS. 2012. Natural Resource Conservation Service Conservation Practice Standard. Nutrient Management. Code 590. NRCS, NHCP January 2012. Washington, DC: USDA Natural Resources Conservation Service.

Waller, J.C. 2009. Endophyte effects on cattle. In Tall Fescue for the Twenty-First Century, eds. H.A. Fribourg, D.B. Hannaway, and C.P. West, 289-310. Agronomy Monographs 53. Madison, WI: American Society of Agronomy, Crop Science Society of America, and Soil Science Society of America. 